\title{
INTCAL98 RADIOCARBON AGE CALIBRATION, 24,000-0 cal BP
}

\author{
MINZE STUIVER, I PAULA J. REIMER, ${ }^{l}$ EDOUARD BARD, ${ }^{2} J$. WARREN BECK, ${ }^{3}$ G. S. BURR, ${ }^{3}$ \\ KONRAD A. HUGHEN, ${ }^{4}$ BERND KROMER,${ }^{5}$ GERRY MCCORMAC, ${ }^{6}$ JOHANNES VAN DER \\ PLICHT ${ }^{7}$ and MARCO SPURK ${ }^{8}$
}

\begin{abstract}
The focus of this paper is the conversion of radiocarbon ages to calibrated (cal) ages for the interval 24,000-0 cal BP (Before Present, 0 cal BP = AD 1950), based upon a sample set of dendrochronologically dated tree rings, uranium-thorium dated corals, and varve-counted marine sediment. The ${ }^{14} \mathrm{C}$ age-cal age information, produced by many laboratories, is converted to $\Delta^{14} \mathrm{C}$ profiles and calibration curves, for the atmosphere as well as the oceans. We discuss offsets in measured ${ }^{14} \mathrm{C}$ ages and the errors therein, regional ${ }^{14} \mathrm{C}$ age differences, tree-coral ${ }^{14} \mathrm{C}$ age comparisons and the time dependence of marine reservoir ages, and evaluate decadal vs. single-year ${ }^{14} \mathrm{C}$ results. Changes in oceanic deepwater circulation, especially for the $16,000-11,000 \mathrm{cal} B \mathrm{BP}$ interval, are reflected in the $\Delta^{14} \mathrm{C}$ values of INTCAL98.
\end{abstract}

\section{INTRODUCTION}

The radiocarbon age time frame has been used extensively during the past 50 years in many disciplines. Because uncorrected ${ }^{14} \mathrm{C}$ ages and calibrated (cal) ages differ in a time-dependent fashion, the conversion of ${ }^{14} \mathrm{C}$ ages to cal ages is especially important for improving the validity of time estimates. Participants at the 16th International Radiocarbon Conference at Groningen (16-20 June 1997) discussed and recommended an update of previous calibration publications (Stuiver and Kra 1986; Stuiver, Long and Kra 1993). Following the advice of the international radiocarbon community, we present here an extended ${ }^{14} \mathrm{C}$ calibration data set, INTCAL98, that caps the 20 th century ${ }^{14} \mathrm{C}$ age calibration efforts.

Dendrochronology provided the cal ages of the wood used for ${ }^{14} \mathrm{C}$ dating; their accuracy is established through standard dendrochronological checks and counterchecks for double or missing tree rings. The Irish oak (Pilcher et al. 1984) and the German oak and pine chronologies (Spurk et al. 1998) play a crucial role. The German oak chronology provides absolute counts of dendroyears back to $c a .10,300$ cal BP. ${ }^{14} \mathrm{C}$ matching of the latest part of a floating German pine chronology to the earliest absolutely dated German oak extends this chronology to 11,857 cal BP. Errors in the matching may amount to 20 cal years (Kromer and Spurk 1998).

Uranium-thorium (U-Th) dating of corals extends the cal age range (Bard et al. 1998; Burr et al. 1998; Edwards et al. 1993). Whereas tree-ring ${ }^{14} \mathrm{C}$, via the photosynthetic cycle, equilibrates with atmospheric carbon dioxide, corals equilibrate with mixed-layer ocean bicarbonate. The slightly lower ${ }^{14} \mathrm{C}$ activity (per gram of carbon) of the mixed layer, relative to the atmosphere, results in an offset (the ${ }^{14} \mathrm{C}$ reservoir age correction) between "atmospheric" and "oceanic" ${ }^{14} \mathrm{C}$ ages of samples with identical cal age. The reservoir correction $\left(509 \pm 25{ }^{14} \mathrm{C}\right.$ yr over the $12,000-10,000$ cal BP interval) was fixed by comparing Early Holocene tree-ring and coral ${ }^{14} \mathrm{C}$ activities of contemporaneous samples. Adding coral results extends the calibration curve to $24,000 \mathrm{cal}$ BP. Although only two

\footnotetext{
'Quaternary Isotope Laboratory, University of Washington, Seattle, Washington 98195-1360 USA

${ }^{2}$ CEREGE, Europôle de l'Arbois, B.P. 80, 13545 Aix-en-Provence Cedex 4, France

${ }^{3}$ Physics Department, University of Arizona, Tucson, Arizona 85721-0081 USA

${ }^{4}$ Department of Earth and Planetary Sciences, Harvard University, Cambridge, Massachusetts 02138 USA

${ }^{5}$ Heidelberger Akademie der Wissenschaften, Im Neuenheimer Feld 366, D-69120 Heidelberg, Germany

${ }^{6}$ Radiocarbon Laboratory, The Queen's University, Belfast BT7 1NN, Northern Ireland

${ }^{7}$ Centrum voor Isotopen Onderzoek, Rijksuniversiteit Groningen, Nijenborgh 4, 9747 AG Groningen, The Netherlands

${ }^{8}$ Universität Hohenheim, Institut für Botanik-210, D-70593 Stuttgart, Germany
} 
coral measurements exist for the 40,000-24,000 cal BP interval (Bard et al. 1998), they seem to point towards increasing differences between ${ }^{14} \mathrm{C}$ and cal ages.

Terrestrial varve chronologies, to be discussed in a future issue of RADIOCARBON, have not been used for construction of INTCAL98. A floating marine varve chronology, however, was used to strengthen the coral information from the $14,500-11,700 \mathrm{cal}$ BP interval. To fix absolute time, the younger varve ${ }^{14} \mathrm{C}$ ages were matched with tree-ring ${ }^{14} \mathrm{C}$ ages (normalized on marine ${ }^{14} \mathrm{C}$ level).

Decadal wood samples were emphasized in RADIOCARBON's 1986 and 1993 calibration issues. The ${ }^{14} \mathrm{C}$ content of a 10 -yr wood sample, however, is not necessarily a perfect reflection of the atmospheric ${ }^{14} \mathrm{C}$ level of that decade. Tree-ring ${ }^{14} \mathrm{C}$ does not represent the seasons equally because a major portion of the wood is formed in spring and early summer. Tree-ring thickness also differs from year to year, causing variable annual ${ }^{14} \mathrm{C}$ contributions to the decadal average.

Decadal results were used in 1986 and 1993 for the construction of a (mostly) decadal Seattle calibration curve (Stuiver and Becker 1986, 1993). Combining these results with those obtained by Belfast for bidecadal samples led to a 20-yr calibration curve which has until now been used for most age calibrations (Pearson and Stuiver 1993; Pearson, Becker and Qua 1993; Stuiver and Reimer 1993).

Many ${ }^{14} \mathrm{C}$ ages have been determined on dendrodated wood covering only a couple of years. Instead of disregarding these high-precision measurements, we used a different approach for the INTCAL98 calibration curve. INTCAL98 "decadal" ${ }^{14} \mathrm{C}$ is obtained by averaging full-decadal and part-decadal (single- or multiple-year) results. ${ }^{14} \mathrm{C}$ ages of samples covering $20 \mathrm{yr}$ also are included by allocating to each decade the bidecadal age with a standard deviation $(\sigma)$ multiplied by 1.4. Adding these data to the pool of "actual" decadal information ultimately produces ${ }^{14} \mathrm{C}$ ages with a smaller $\sigma$.

\section{DECADAL VERSUS SINGLE-YEAR AGE CALIBRATION}

The smaller INTCAL98 $\sigma$ comes at a price, of course, because ${ }^{14} \mathrm{C}$ dates of single years and decadal averages need not be identical. The impact on the decadal averages can be assessed by comparing single-year ${ }^{14} \mathrm{C}$ ages (Stuiver, Reimer and Braziunas 1998: Table 2) to decadal ones.

Part of single-year $\Delta^{14} \mathrm{C}$ (expressed as the per mil (\%o) deviation of tree-ring ${ }^{14} \mathrm{C}$ activity from NBS oxalic acid activity, corrected for isotope fractionation, Stuiver and Polach 1977) is tied to 11-yrcycle solar modulation of atmospheric ${ }^{14} \mathrm{C}$ production. Pacific Northwest single-year data (when averaged with those of a Kodiak Island tree) yield a three-year moving average for the AD 18971945 interval with 11 -yr-cycle $\Delta^{14} \mathrm{C}$ modulation averaging $2.5 \%$ (peak to peak) over four cycles (Stuiver and Braziunas 1998). Twenty ${ }^{14} \mathrm{C}$ years appears to be an upper limit for single-yr ${ }^{14} \mathrm{C}$ age change induced by the 11 -yr cycle. The standard deviation introduced by 11 -yr modulation around the long-term (e.g., decadal average) trend is a much smaller $8{ }^{14} \mathrm{C}$ yr (as derived from a $2.5 \%$ o peakto-peak sinusoidal $\Delta{ }^{14} \mathrm{C}$ cycle).

A frequency distribution of single-year (AD 1510-1950) ${ }^{14} \mathrm{C}$ age differences around a smoothing spline (the spline closely resembles a 10-yr moving average) agrees with a Gaussian scatter $\sigma_{2}$ of $14.4{ }^{14} \mathrm{C}$ yr (Fig. 1). The laboratory errors reported with the data predict an average measurement standard deviation $\sigma_{1}$ of $13.4{ }^{14} \mathrm{C}$ yr for these ${ }^{14} \mathrm{C}$ age differences. If the additional variability $\sigma_{\mathrm{n}}$ is attributed to natural causes (e.g., the 11-yr cycle) then, since $\sigma_{2}{ }^{2}=\sigma_{1}{ }^{2}+\sigma_{\mathrm{n}}{ }^{2}$, the increase in sigma from 13.4 to $14.4{ }^{14} \mathrm{C}$ yr would be accounted for by $\sigma_{n}=5{ }^{14} \mathrm{C}$ yr. The same technique, when applied to a three-year (instead of single-year) moving average, again produces natural ${ }^{14} \mathrm{C}$ variance with $\sigma_{\mathrm{n}}$ $=5{ }^{14} \mathrm{C} \mathrm{yr}\left(\sigma_{1}=8.4{ }^{14} \mathrm{C}\right.$ yr and $\left.\sigma_{2}=10{ }^{14} \mathrm{C} \mathrm{yr}\right)$. 


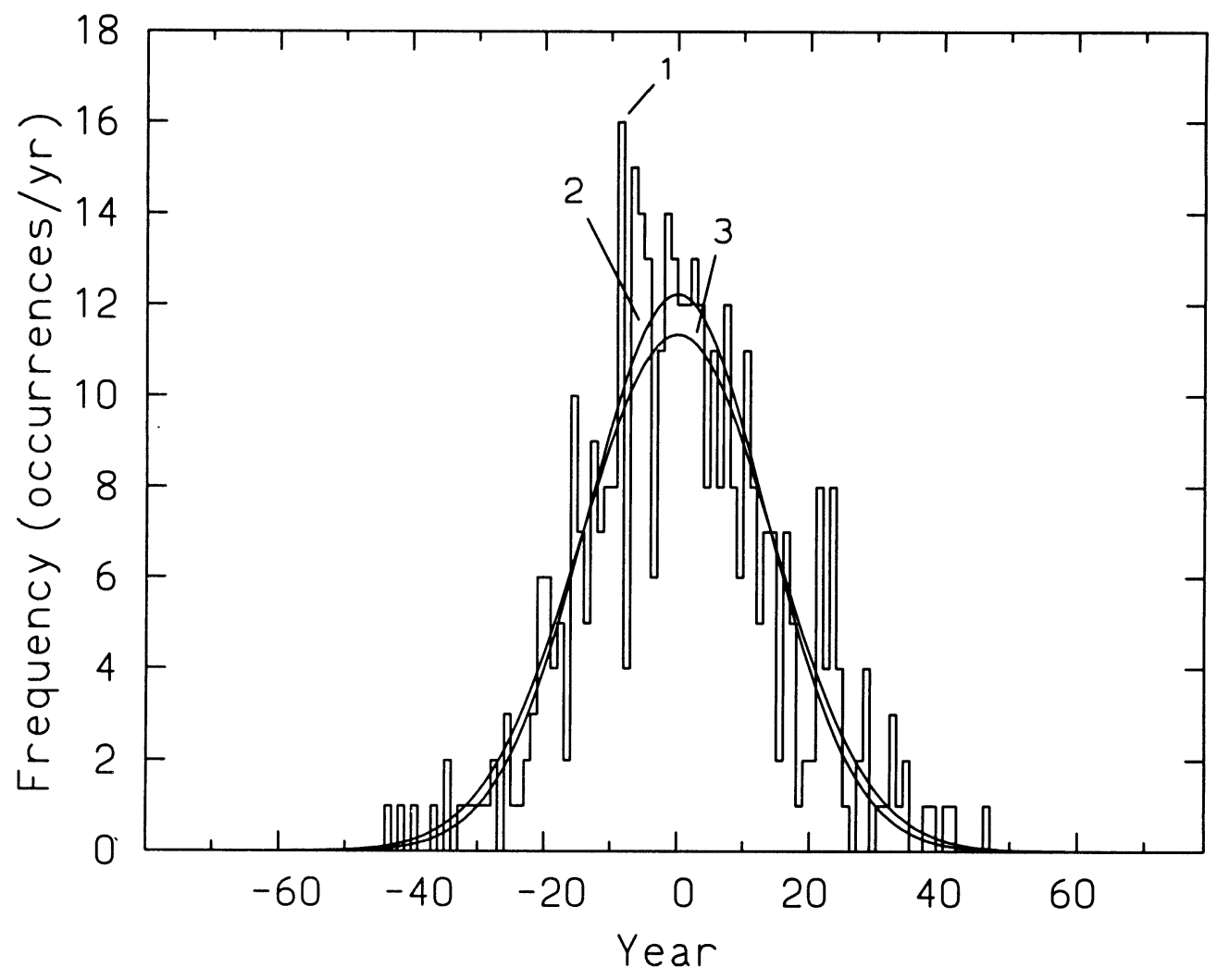

Fig. 1. Plots of the actual frequency distribution of single-year ${ }^{14} \mathrm{C}$ age differences from smoothed spline fitted to a 10 year moving average (AD 1510-1950, diagram indicated by 1), the Gaussian distribution with scatter $\sigma=14.4$ yr (curve 3 ), and the Gaussian distribution constructed from the average measurement standard deviation with $\sigma=13.4{ }^{14} \mathrm{C} \mathrm{yr}$ (curve 2)

The above calculations suggest single-year and three-year natural variability (around long-term decadal trends) with $\sigma$ 's in the 5 to $8{ }^{14} \mathrm{C}$ yr range (the frequency distribution and solar considerations are for different time intervals). Natural variability plays a role in constructing INTCAL98 "decades" from a mixture of decadal and single (or multiple) year results. Given the above considerations, most INTCAL98 decades should deviate, on average, by only a couple of ${ }^{14} \mathrm{C}$ years from "pure" decadal ones. This statement, of course, only applies to INTCAL98 decades constructed from multiple measurements. When constructing a (hypothetical) INTCAL 98 decade from only one nondecadal ${ }^{14} \mathrm{C}$ age, the INTCAL 98 decadal value would contain, relative to actual decadal values, an additional $\sigma_{\mathrm{n}}$ in the 5 to $8{ }^{14} \mathrm{C}$ yr range.

Information contained in single-year (and three-year) results will be lost to the tune of 5 to $8{ }^{14} \mathrm{C} \mathrm{yr}$ $(\sigma$ 's) when constructing decadal data. Conversely, when calibrating single-year results against the decadal INTCAL98 curve, the single-year ${ }^{14} \mathrm{C}$ ages will differ from decadal ${ }^{14} \mathrm{C}$ ages $(\sigma$ in the 5 to $8{ }^{14} \mathrm{C}$ yr range). Here we recommend, prior to calibration, an increase of sample standard deviation $\sigma_{x}$ to $\sqrt{ }\left(\sigma_{x}^{2}+8^{2}\right)$. The correction is very minor for most samples and only plays a role in high-precision determinations (a $\sigma_{\mathrm{x}}$ of, e.g., $10{ }^{14} \mathrm{C} \mathrm{yr}$ transforms into $13{ }^{14} \mathrm{C} \mathrm{yr}$ ). 


\section{TREE-RING ${ }^{14} \mathrm{C}$ AGE OFFSETS, "ERROR MULTIPLIERS” AND MINOR ADJUSTMENTS}

The major laboratories involved in the determination of tree-ring ${ }^{14} \mathrm{C}$ for INTCAL98 purposes are Seattle (S), Belfast (B), Heidelberg (H), and Pretoria/Groningen (P/G). For the tree-ring cal age portion of the INTCAL98 calibration curve we used the data sets reported in this calibration issue (Stuiver, Reimer and Braziunas 1998; Kromer and Spurk 1998; and McCormac et al. 1998a), and previously reported ${ }^{14} \mathrm{C}$ sequences (Vogel and van der Plicht 1993; Pearson, Becker and Qua 1993; Kromer et al. 1986; McCormac et al. 1998b). When applicable, the older German oak and pine chronologies were adjusted in conformity with the Spurk et al. (1998) corrections.

The ${ }^{14} \mathrm{C}$ age differences of samples of identical cal age yield an average offset and (scatter) standard deviation $\sigma_{2}$. The $\sigma_{2}$ can be compared to the standard deviation $\left(\sigma_{1}\right)$ predicted for the ${ }^{14} \mathrm{C}$ age differences from the laboratory reported errors. The increase in variance (excess variance) $\sigma_{\mathrm{E}}$ is derived from $\sigma_{\mathrm{E}}^{2}=\sigma_{2}^{2}-\sigma_{1}^{2}$, whereas the ratio $\sigma_{2} / \sigma_{1}$ yields the "error multiplier" $\mathrm{k}$ (Stuiver 1982).

The above statistical considerations are valid for ${ }^{14} \mathrm{C}$ determinations of identical samples. However, the samples to be compared here are rarely fully identical, because the time over which the sample was formed may differ (e.g., $10 \mathrm{yr} v s .3 \mathrm{yr}$ ). Furthermore, cal ages (time-midpoints) of the wood used by different laboratories samples differ. Different selection criteria (e.g., should two samples be compared if one is a 10 -yr and the other a 3 -yr sample, and the difference in midpoints is ten years) yield variations in $\sigma_{\mathrm{E}}\left(\right.$ and $\mathrm{k}$ ) estimates. Given these uncertainties, the $\sigma_{\mathrm{E}}$ and $\mathrm{k}$ calculations are only approximate.

The interlaboratory comparisons provide information on the sum total of uncertainty tied to the processes of wood allocation, dendroage determination, sample pretreatment, laboratory ${ }^{14} \mathrm{C}$ determination, regional ${ }^{14} \mathrm{C}$ differences and individual tree ${ }^{14} \mathrm{C}$ differences.

${ }^{14} \mathrm{C}$ results determined in different laboratories for samples of the "same" dendroage usually yield offsets in the $0-20{ }^{14} \mathrm{C}$ yr range. Values twice as large are occasionally encountered. The larger offsets are, for reasons unknown, over shorter (century-scale) intervals.

Offset information can be derived from ${ }^{14} \mathrm{C}$ age comparisons when results are available from three or more laboratories over an identical time interval. Because average $S{ }^{14} \mathrm{C}$ ages between 6600 and $5800 \mathrm{cal} B C$ differed more than $2 \sigma$ from those reported by $\mathrm{H}$ and $\mathrm{B}$, we increased the $\mathrm{S}{ }^{14} \mathrm{C}$ ages over this interval by $27{ }^{14} \mathrm{C}$ yr for INTCAL98 purposes. The offset correction is relatively mild: we allow a $2 \sigma$ difference between the corrected $\mathrm{S}$ average and the average of the other laboratories. The same technique reduces Heidelberg ${ }^{14} \mathrm{C}$ ages by 31,27 , and 26 yr for, respectively, $4400-4200,5200$ 5000 , and $7200-7000 \mathrm{cal} \mathrm{BC}$. The ${ }^{14} \mathrm{C}$ age offsets (number of comparisons $=\mathrm{n}$ ) between the individual laboratory data sets used for INTCAL98 construction (the minor corrections discussed above are included), as well as $\sigma_{1}, \sigma_{\mathrm{E}}$, and $\mathrm{k}$, are listed in Table 1 .

The trees forming the dendrodated portion of the INTCAL98 curve are predominantly from South Germany, Ireland, California and Washington. For the data sets used for INTCAL98 construction we list in Table 2 tree species, regions, offsets, $\sigma_{1}, \sigma_{\mathrm{E}}$ and $\mathrm{k}$ (relative to Seattle). The offsets need not be specifically species-related, and ${ }^{14} \mathrm{C}$ results for trees from different regions may reflect laboratory, as well as regional, influences.

Time-dependent millennium offsets, relative to the INTCAL98 curve, are listed in Table 3 . The largest millennium offset of $26^{14} \mathrm{C} \mathrm{yr}$, based on a small number of points, is not very significant given the $\pm 10{ }^{14} \mathrm{C}$ yr standard deviation. The complete data sets of individual laboratories differ only marginally (up to $11{ }^{14} \mathrm{C}$ yr) from INTCAL98. 
TABLE 1. A comparison of Seattle, Belfast, Pretoria/Groningen (P/G) and Heidelberg ${ }^{14} \mathrm{C}$ ages of dendrodated wood. The offset equals the weighted mean ${ }^{14} \mathrm{C}$ age difference of samples for which the midpoint cal ages fall within the same decade. $\mathrm{n}$ is the number of comparisons, $\sigma_{1}$ is the predicted average standard deviation in single ${ }^{14} \mathrm{C}$ age comparisons (based on quoted laboratory errors), $\sigma_{\mathrm{E}}$ represents the difference between the observed standard deviation in the age difference $\left(\sigma_{2}\right)$ and $\sigma_{1}$ (see text). The $\sigma_{2} / \sigma_{1}$ ratio $=\mathrm{k}$. Offset, $\sigma_{1}$ and $\sigma_{\mathrm{E}}$ are in ${ }^{14} \mathrm{C}$ yr.

\begin{tabular}{lcccccl}
\hline Laboratories & Offset & $\sigma_{1}$ & $\mathrm{~s}_{\mathrm{E}}$ & $\mathrm{k}$ & $\mathrm{n}$ & Cal yr interval \\
\hline Belfast - Seattle & $12 \pm 1$ & 27 & 22 & 1.29 & 866 & $7745 \mathrm{BC}-\mathrm{AD} 1935$ \\
Heidelberg - Seattle & $19 \pm 2$ & 40 & 22 & 1.14 & 230 & $9665-4085 \mathrm{BC}$ \\
P/G - Seattle & $17 \pm 1$ & 22 & 17 & 1.26 & 194 & $3905-1935 \mathrm{BC}$ \\
Heidelberg - Belfast & $30 \pm 3$ & 43 & 30 & 1.22 & 142 & $7715-4075 \mathrm{BC}$ \\
P/G - Belfast & $-2 \pm 2$ & 26 & 23 & 1.33 & 194 & $3905-1935 \mathrm{BC}$ \\
\hline
\end{tabular}

TABLE 2. A comparison of tree-ring ${ }^{14} \mathrm{C}$ results of laboratories involved in the INTCAL98 project. (See Table 1 for nomenclature.) Offset, $\sigma_{1}$ and $\sigma_{\mathrm{E}}$ are in ${ }^{14} \mathrm{C} \mathrm{yr}$.

\begin{tabular}{lcccccl}
\hline Laboratories & Offset & $\sigma_{1}$ & $\mathrm{~s}_{\mathrm{E}}$ & $\mathrm{k}$ & $\mathrm{N}$ & Cal yr interval \\
\hline $\begin{array}{l}\text { Belfast - Seattle } \\
\text { Irish oak - U.S. conifers }\end{array}$ & $14 \pm 2$ & 24 & 11 & 1.1 & 202 & $150 \mathrm{BC}-\mathrm{AD} 1940$ \\
$\begin{array}{l}\text { Belfast - Seattle } \\
\text { Irish oak - German oak }\end{array}$ & $11 \pm 1$ & 26 & 22 & 1.3 & 501 & 5210 BC-AD 30 \\
$\begin{array}{l}\text { P/G - Seattle } \\
\text { both German oak }\end{array}$ & $17 \pm 2$ & 22 & 17 & 1.3 & 194 & $3910-1930 \mathrm{BC}$ \\
$\begin{array}{l}\text { Belfast - Seattle } \\
\text { both German oak }\end{array}$ & $10 \pm 2$ & 32 & 35 & 1.5 & 181 & $7750-5260 \mathrm{BC}$ \\
$\begin{array}{l}\text { Heidelberg - Seattle } \\
\text { both German oak }\end{array}$ & $21 \pm 3$ & 41 & 28 & 1.2 & 128 & $7720-4080 \mathrm{BC}$ \\
$\begin{array}{l}\text { Heidelberg - Seattle } \\
\text { both German pine }\end{array}$ & $16 \pm 4$ & 38 & 12 & 1.0 & 102 & $9670-8000 \mathrm{BC}$ \\
\hline
\end{tabular}

A portion of the variance increase (expressed by $\sigma_{\mathrm{E}}$ or $\mathrm{k}$ ) is tied to factors unrelated to the laboratory operation (e.g., variable regional ${ }^{14} \mathrm{C}$ differences). Previously (in 1993) $\mathrm{k}=1.6$ was used to calculate the errors in the decadal Seattle ${ }^{14} \mathrm{C}$ age calibration curve. The Table 1 data suggest $\mathrm{k}$ values of 1.14 to 1.33 . A conservative $\mathrm{k}=1.3$ was chosen for the calculation of the errors in decadal INTCAL98 tree-ring ${ }^{14} \mathrm{C}$ ages.

\section{HEMISPHERIC AND REGIONAL OFFSETS}

Latitude-dependent differences in ocean surface area, and ocean circulation, cause corresponding latitude-dependent ${ }^{14} \mathrm{C}$ transfer to and from the oceans. Rapid tropospheric mixing of air masses counteracts the oceanic influence but does not fully nullify the atmospheric response. As suggested by an atmospheric transport model (GISS GCM), regional atmospheric $\Delta^{14} \mathrm{C}$ gradients may amount to several per mil, especially between Northern and Southern Hemispheric localities (Braziunas, Fung and Stuiver 1995).

The INTCAL98 tree-ring data set is based on a mix of mid-latitude Northern Hemisphere trees (Germany, Ireland, Washington, Oregon and California). The atmospheric transport model predicts $\Delta^{14} \mathrm{C}$ 
TABLE 3. Offsets (millennial time separation) between individual laboratory and INTCAL98 (I) results. $\mathrm{P} / \mathrm{G}$ is Pretoria/Groningen. All parameters following the cal age interval are in ${ }^{14} \mathrm{C}$ yr. (See Table 1 for nomenclature.)

\begin{tabular}{|c|c|c|c|c|c|c|c|c|}
\hline \multirow[b]{2}{*}{ Cal age interval } & \multicolumn{2}{|c|}{ I - Seattle } & \multicolumn{2}{|c|}{ I - Heidelberg } & \multicolumn{2}{|c|}{ I - Belfast } & \multicolumn{2}{|c|}{$\mathrm{I}-\mathrm{P} / \mathrm{G}$} \\
\hline & Offset & $\sigma_{1}$ & Offset & $\sigma_{1}$ & Offset & $\sigma_{1}$ & Offset & $\sigma_{1}$ \\
\hline $10-9$ ka BC & $3 \pm 4$ & 29 & $-4 \pm 5$ & 36 & & & & \\
\hline $9-8 \mathrm{ka} \mathrm{BC}$ & $7 \pm 3$ & 28 & $-7 \pm 4$ & 33 & & & & \\
\hline $8-7 \mathrm{ka} \mathrm{BC}$ & $0 \pm 3$ & 28 & $-12 \pm 5$ & 39 & $11 \pm 4$ & 31 & & \\
\hline $7-6 \mathrm{ka} \mathrm{BC}$ & $2 \pm 2$ & 23 & $-11 \pm 5$ & 41 & $-1 \pm 3$ & 29 & & \\
\hline $6-5 \mathrm{ka} \mathrm{BC}$ & $9 \pm 2$ & 23 & $-26 \pm 10$ & 40 & $-16 \pm 3$ & 26 & & \\
\hline $5-4 \mathrm{ka} \mathrm{BC}$ & $7 \pm 2$ & 21 & $-19 \pm 4$ & 34 & $0 \pm 3$ & 27 & & \\
\hline $4-3 \mathrm{ka} \mathrm{BC}$ & $10 \pm 2$ & 17 & & & $-8 \pm 2$ & 24 & $-5 \pm 2$ & 16 \\
\hline $3-2 \mathrm{ka} \mathrm{BC}$ & $9 \pm 2$ & 18 & & & $-6 \pm 2$ & 21 & $-7 \pm 2$ & 19 \\
\hline $2-1 \mathrm{ka} \mathrm{BC}$ & $0 \pm 2$ & 20 & & & $0 \pm 2$ & 24 & $3 \pm 6$ & 18 \\
\hline $1-0 \mathrm{ka} \mathrm{BC}$ & $2 \pm 2$ & 18 & & & $-4 \pm 2$ & 23 & & \\
\hline $\mathrm{AD} 0-1 \mathrm{ka}$ & $3 \pm 2$ & 18 & & & $-9 \pm 3$ & 26 & & \\
\hline $\mathrm{AD} 1-2 \mathrm{ka}$ & $1 \pm 1$ & 11 & & & $-13 \pm 2$ & 19 & & \\
\hline 10 ka BC - AD 2 ka & $3 \pm 1$ & 21 & $-11 \pm 2$ & 37 & $-6 \pm 1$ & 25 & $-6 \pm 1$ & 18 \\
\hline
\end{tabular}

differences of $\sim 1 \%$ or these areas. Such differences are at the limit of ${ }^{14} \mathrm{C}$ dating and difficult to measure. The fine structure in ocean circulation (e.g., in coastal waters) and differences in regional carbon cycle sources and sinks (e.g., permafrost areas, Damon et al. 1996) increase Northern Hemispheric $\Delta^{14} \mathrm{C}$ variability. The location-dependent $\Delta{ }^{14} \mathrm{C}$ offsets also need not be constant over time. Measurements (not necessarily covering identical time intervals but mostly of the 19th century) of Northern Hemispheric localities yield differences (relative to Washington) of $c a .-21, c a .+22$, $16 \pm 9,-26 \pm 6$ (AD 1545-1615), $2 \pm 6$ (AD 1615-1715), and $14 \pm 3{ }^{14} \mathrm{C}$ yr for, respectively, the Santa Catalina Mountains in Arizona (Damon 1995), Mackenzie River Valley, Canada (Damon 1995), Dean of Forest oak, England (Stuiver and Quay 1981), Russia (high latitude, two comparisons) and Kodiak Island, Alaska (Stuiver and Braziunas 1998). Furthermore, Irish oak yielded $41 \pm$ $9{ }^{14} \mathrm{C}$ yr younger dates than bristlecone pine of Nevada (McCormac et al. 1995) and German oak was $23 \pm 6{ }^{14} \mathrm{C}$ yr younger than California sequoia (Stuiver 1982).

Southern Hemisphere offset measurements (Stuiver and Braziunas 1998) yield $25 \pm 7{ }^{14} \mathrm{C}$ yr for Tasmania-Washington (19th century), and $38 \pm 5{ }^{14} \mathrm{C}$ yr and $21 \pm 5{ }^{14} \mathrm{C}$ yr for South ChileWashington (respectively, AD 1670-1722 and 19th century). Other offsets are $40 \pm 5{ }^{14} \mathrm{C}$ yr for South Africa-the Netherlands (AD 1835-1900, Vogel et al. 1993) and $27 \pm 5{ }^{14} \mathrm{C}$ yr for New ZealandBritish Isles (AD 1720-1885, McCormac et al. 1998a).

For the 1993 calibration program (Stuiver and Reimer 1993), a $40{ }^{14} \mathrm{C}$ yr correction was recommended for the entire Southern Hemisphere. The recent measurements of 19th century wood (Tasmania, New Zealand, South Chile) are in line with a smaller Southern Hemispheric offset of $24 \pm 3$ ${ }^{14} \mathrm{C}$ yr.

The above Southern Hemisphere-Washington offset is for "natural" conditions. During the first half of the 20th century, fossil fuel $\mathrm{CO}_{2}$ release depressed atmospheric ${ }^{14} \mathrm{C}$ levels to a greater extent in the Northern Hemisphere. Whereas 19 th century Chile/Tasmania ${ }^{14} \mathrm{C}$ ages are about 23 yr older than those of Washington, the offset is reduced during the first half of the 20th century. There is even a switch to younger Southern Hemispheric ages $c a$. AD 1940 (Stuiver and Braziunas 1998; McCormac et al.1998b). 


\section{TREE-RING AND CORAL ${ }^{14} \mathrm{C}$ AGE DIFFERENCES}

The ${ }^{14} \mathrm{C}$ ages of dendrodated tree-rings, together with ${ }^{230} \mathrm{Th} /{ }^{234} \mathrm{U}$-dated corals, ultimately yield the ${ }^{14} \mathrm{C}$ age axis of the INTCAL98 curve. Tree-cellulose ${ }^{14} \mathrm{C}$ activity reflects the atmospheric ${ }^{14} \mathrm{C} /{ }^{12} \mathrm{C}$ ratio of $\mathrm{CO}_{2}$, after correction for isotope fractionation. Similarly, coral-carbonate ${ }^{14} \mathrm{C}$ activity mirrors the mixed ocean layer ${ }^{14} \mathrm{C} /{ }^{12} \mathrm{C}$ ratio. The ${ }^{14} \mathrm{C}$-specific activity in the mixed layer (depth $\sim 75 \mathrm{~m}$ ) is lower than that in the atmosphere because mixed-layer ${ }^{14} \mathrm{C}$ depends on atmospheric as well as deep ocean ${ }^{14} \mathrm{C}$ supply (the main cause for the lower ${ }^{14} \mathrm{C}$ activity of the deep ocean is radioactive decay during its $\sim 1000 \mathrm{yr}$ isolation from the atmosphere). Because ${ }^{14} \mathrm{C}$ ages are based on comparison to a (postulated) stable atmospheric ${ }^{14} \mathrm{C}$ level (via the oxalic acid standard), the coral ${ }^{14} \mathrm{C}$ dates have to be corrected for mixed layer ${ }^{14} \mathrm{C}$ reservoir $(\mathrm{R})$ ages.

Late Holocene (preanthropogenic) ${ }^{14} \mathrm{C}$ reservoir ages in the Atlantic, Pacific and Indian Oceans depend on geographic latitude. As luck has it, the tropical areas where coral reefs are formed are part of the oceanic $40^{\circ} \mathrm{S}-40^{\circ} \mathrm{N}$ region with a fairly constant (non-latitude dependent) pre-bomb R of 300 to $500{ }^{14} \mathrm{C}$ yr (Bard et al. 1994; Bard 1988; Edwards et al. 1993; Burr et al. 1998 with 35 pre-bomb samples yielding $494 \pm 10 \mathrm{yr}$ for Vanuatu).

$\mathrm{R}$ is the ${ }^{14} \mathrm{C}$ age difference between samples grown in equilibrium with the atmosphere, and the mixed layer of the ocean. To make tree-ring and coral results from the 19th century compatible, coral ${ }^{14} \mathrm{C}$ dates should be reduced by 300 to $500{ }^{14} \mathrm{C}$ yr. A similar correction does not automatically apply to older samples because ocean and climate variables (rates of deepwater formation and upwelling, average wind speed, ice cover, etc.) influence $\mathrm{R}$ values (Bard et al. 1994).

Tropical paleo- $\mathrm{R}$ values of the Early Holocene can be estimated from tree-ring (INTCAL98 values) and coral ${ }^{14} \mathrm{C}$ age differences. Estimated errors used for the following ${ }^{14} \mathrm{C}$ age difference calculations are $2 \sigma$ for coral ages, and $1 \sigma$ for INTCAL98 tree-ring ages.

For the 11,800-8300 cal BP interval, the Bard et al. (1998), Burr et al. (1998), and Edwards et al. (1993) coral data yield tree-ring-coral offsets of, respectively, $298 \pm 33{ }^{14} \mathrm{C}$ yr $(11,590-8450 \mathrm{cal} \mathrm{BP}$, number of comparisons $n=19), 537 \pm 38{ }^{14} \mathrm{C}$ yr $(11,770-11730 \mathrm{cal} \mathrm{BP}, \mathrm{n}=5)$ and $587 \pm 29(11,045$ $8363 \mathrm{cal} \mathrm{BP}, \mathrm{n}=10)$. Omitting one outlier from the Edwards et al. data reduces the $587 \pm 29^{14} \mathrm{C} \mathrm{yr}$ to $502 \pm 33{ }^{14} \mathrm{C}$ yr. Without the outlier, the weighted average offset for all samples is $440 \pm 21{ }^{14} \mathrm{C} \mathrm{yr}$.

Differences between oceans are relatively small: $\mathrm{R}$ is $406 \pm 65{ }^{14} \mathrm{C}$ yr $(11,590-8450 \mathrm{cal} \mathrm{BP}, \mathrm{n}=6)$ for the Atlantic Ocean and $440 \pm 20{ }^{14} \mathrm{C}$ yr $(11,770-8363$ cal BP, $n=27)$ for the Pacific (one outlier omitted). However, there is the suggestion of substantial Pacific intraocean $\mathrm{R}$ difference with $\mathrm{R}=$ $\sim 300{ }^{14} \mathrm{C}$ yr for Tahiti $v s$. $\mathrm{R}=\sim 500{ }^{14} \mathrm{C}$ yr for New Guinea and Vanuatu.

Between $10,000-8,000$ and $12,000-10,000$ cal BP the coral data generate a weighted mean $\mathrm{R}$ value of, respectively, $414 \pm 31{ }^{14} \mathrm{C} \mathrm{yr}(\mathrm{n}=12)$ and $509 \pm 25{ }^{14} \mathrm{C} \mathrm{yr}(\mathrm{n}=21)$. Omitting the outlier reduces the latter to $R=451 \pm 26{ }^{14} \mathrm{C}$ yr. The older sample ages appear to have slightly larger $R$ 's, as depicted by the 1000 yr averages in Figure 2. Good agreement between mixed-layer corrected coral dates and tree-ring ${ }^{14} \mathrm{C}$ dates (Fig. 3) is obtained when using $\mathrm{R}=500$ and $400{ }^{14} \mathrm{C}$ yr for, respectively, the $12,000-10,000$ cal BP and $10,000-8000$ cal BP intervals.

Future adjustments of the pine-oak chronology, if any, will influence the derived $\mathrm{R}$ values. The 100 ${ }^{14} \mathrm{C}$ yr $\mathrm{R}$ "increase" is perhaps tied to missing rings in the earliest part of the pine tree-ring chronology. Given our current state of knowledge, however, we do accept an $\mathrm{R}$ value of $500{ }^{14} \mathrm{C} \mathrm{yr}$ for the $12,000-10,000$ cal BP interval, and postulate the same tropical R for the Late Glacial ocean. 


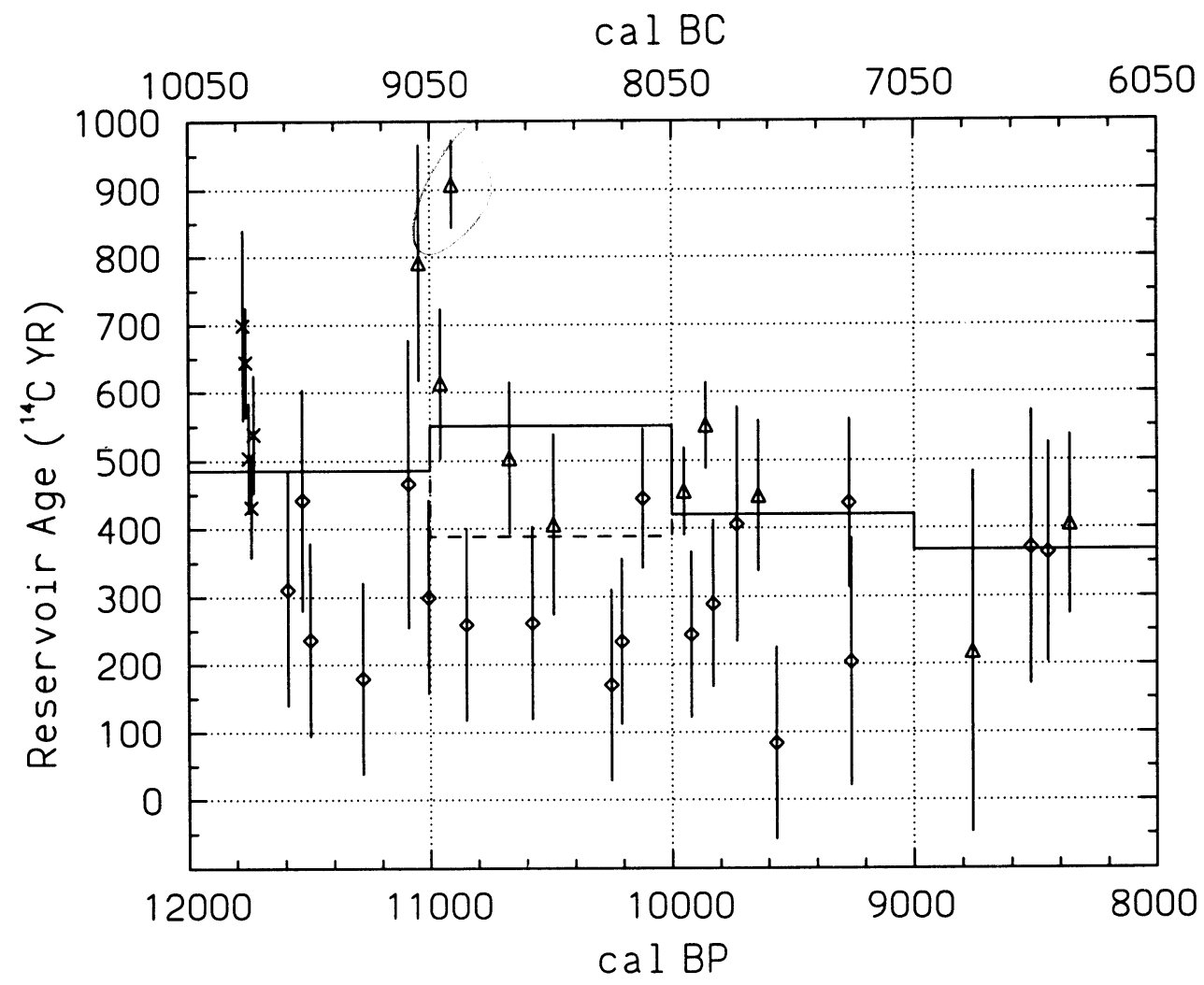

Fig. 2. Reservoir ages $\left({ }^{14} \mathrm{C}\right.$ age difference between coral and tree-ring samples of similar cal age) between 12,000 and $8000 \mathrm{cal} \mathrm{BP}$. Coral measurements given here and in the following figures are from Bard et al. $1998(\diamond)$, Burr et al. 1998 ( $X)$, Edwards et al. $1993(\Delta)$. R values averaged over millennia are represented by the solid line. The dashed line is the $\mathrm{R}$ value for the $11,000-10,000$ cal BP millennium when omitting the $900{ }^{14} \mathrm{C}$ yr data point. Vertical bars represent the calculated error in the ${ }^{14} \mathrm{C}$ age difference calculation, based on a $2 \sigma$ error in the coral ${ }^{14} \mathrm{C}$ age determination, and a $1.3 \sigma$ error in the tree-ring ${ }^{14} \mathrm{C}$ age determination.

\section{CORAL ${ }^{14} \mathrm{C}$ AGE VARIABILITY}

The corals are assumed to be ideal closed systems with regard to ${ }^{14} \mathrm{C},{ }^{234} \mathrm{U}$ and ${ }^{234} \mathrm{Th}$ exchange. The overall agreement (Fig. 3) between reservoir-corrected coral (with the reservoir correction averaged over millennia), and tree-ring ${ }^{14} \mathrm{C}$ dates suggests that this condition is fairly well adhered to for carefully collected samples. Nevertheless, the scatter $\sigma_{2}$ of INTCAL98 tree-ring minus reservoir-corrected coral ${ }^{14} \mathrm{C}$ ages $(12,000-8000 \mathrm{cal} \mathrm{BP}, \mathrm{n}=33)$ is $260{ }^{14} \mathrm{C}$ yr, whereas the quoted measuring precision alone produces a $\sigma_{1}=69{ }^{14} \mathrm{C}$ yr, resulting in $\sigma_{\mathrm{E}}=255{ }^{14} \mathrm{C} \mathrm{yr}$ and error multiplier $\mathrm{k}=3.7$. Similar comparisons between tree-ring data sets yield an average $\mathrm{k}$ value of only $\sim 1.3$.

The above calculation uses a fixed $\mathrm{R}$ of 500 and $400 \mathrm{yr}$ for, respectively, 12,000-10,000 cal BP and $10,000-8000 \mathrm{cal}$ BP. Normalizing each individual data set on its own $R$ value (which aligns the average of each individual coral data set with that of the INTCAL98 tree-ring record) yields an improved $\mathrm{k}=2.3$ when the INTCAL98 reservoir-corrected ${ }^{14} \mathrm{C}$ ages are subtracted from the tree-ring ages.

To generate a pre-12,000 cal BP atmospheric record, one has the choice of 1) assuming R.to be constant for each individual site, or 2) assuming average tropical $\mathrm{R}$ to be constant (the $500{ }^{14} \mathrm{C}$ yr dis- 


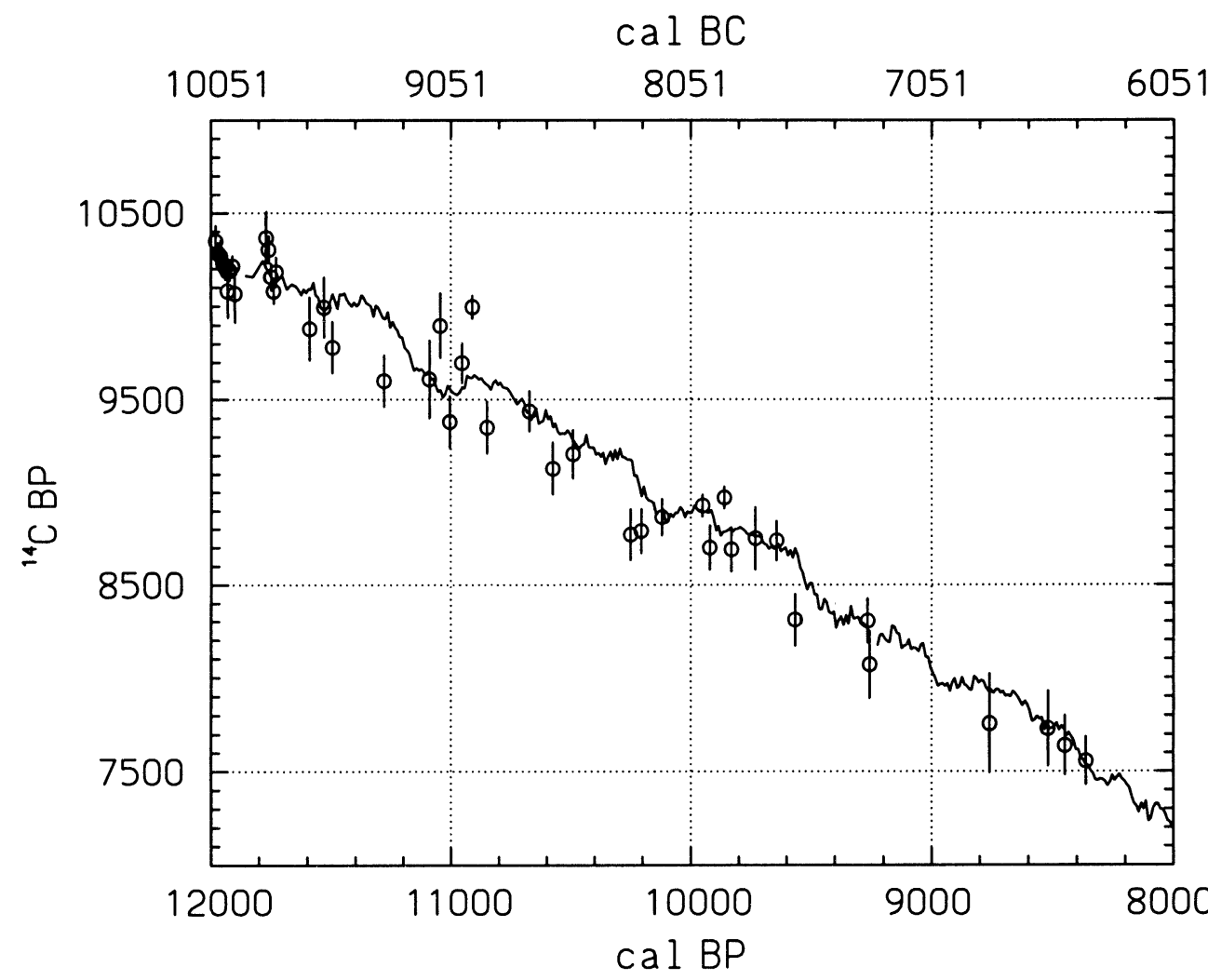

Fig. 3. Position of coral ${ }^{14} \mathrm{C}$ ages ( $\mathrm{O}$ ), relative to INTCAL 98 tree-ring ${ }^{14} \mathrm{C}$ ages (solid line), after a reservoir deficiency correction of the coral ${ }^{14} \mathrm{C}$ ages by 400 and $500{ }^{14} \mathrm{C}$ yr for, respectively, $10,000-8000$ cal BP and $12,000-10,000 \mathrm{cal}$ BP. Vertical bars equal $2 \sigma$ in the coral ${ }^{14} \mathrm{C}$ age measurement.

cussed previously). It is likely (but not proven) that prior to 12,000 cal BP single-site $\mathrm{R}$ variability was larger than average $\mathrm{R}$ variability. We decided to generate the pre-12,000 cal BP atmospheric record by deducting an average tropical $\mathrm{R}=500{ }^{14} \mathrm{C}$ yr from all coral data.

The atmospheric and mixed-layer ${ }^{14} \mathrm{C}$ records are filtered differently by natural processes. Mixedlayer response to postulated decadal atmospheric forcing resembles a $\sim 100-200 \mathrm{yr}$ moving average (e.g., Stuiver, Reimer and Braziunas 1998). Using a similar 200-yr moving average for tree rings, however, does not reduce the coral ${ }^{14} \mathrm{C}$-tree-ring $\sigma_{\mathrm{E}}$. Mechanisms resulting in increased variance could be 1) varying tropical reservoir deficiency $\mathrm{R}, 2$ ) post-depositional ${ }^{14} \mathrm{C}$ activity modification and 3) U/Th age uncertainty.

Post-depositional ${ }^{14} \mathrm{C}$ modification can be accounted for by using twice the standard deviation of the measurement. Many investigators routinely double the measuring precision of coral ${ }^{14} \mathrm{C}$ determinations (Edwards et al. 1993; Bard et al. 1990). For INTCAL98 purposes the assigned standard deviation of coral ${ }^{14} \mathrm{C}$ ages is based on a $2 \sigma$ error in the coral ${ }^{14} \mathrm{C}$ age determination, and a $\mathrm{k}=1.3$ error multiplier similar to the one used for tree-ring derived ${ }^{14} \mathrm{C}$ ages. The combined multiplier of 2.6 accounts for most of the variance actually observed. 


\section{MARINE RESERVOIR AGE CONSIDERATIONS}

Causes for century-scale atmospheric ${ }^{14} \mathrm{C}$ variability include solar modulation of the cosmic-ray flux and ocean circulation change. Model calculated $\mathrm{R}$ values depend on the forcing mechanism. Switching from a solar to an oceanic mode produced century-scale global $\mathrm{R}$ change of $\sim 150{ }^{14} \mathrm{C} \mathrm{yr}$ in a global carbon reservoir model (Stuiver, Reimer and Braziunas 1998).

Splining of the reservoir-corrected coral ${ }^{14} \mathrm{C}$ ages $\left(\mathrm{R}=500{ }^{14} \mathrm{C}\right.$ yr $)$ generates the pre- 11,850 cal BP portion of the "atmospheric" INTCAL98 calibration curve. Before 11,850 cal BP, tropical ocean R is assumed to be identical for the Atlantic, Pacific and Indian Ocean, as well as nonvariable over time. It is difficult to estimate the limits of tropical $\mathrm{R}$ change. Figure 2 suggests tropical $\mathrm{R}$ change of only $\sim 100{ }^{14} \mathrm{C}$ yr for millennia-scale oceanic changes between the end of the Ice Age and $8000 \mathrm{cal}$ BP. A comparison of Cariaco Basin (Hughen et al. 1998) varve and INTCAL98 tree-ring chronologies (discussed in the following section) suggests that decadal- to century-scale tropical $\mathrm{R}$ variability is restricted to $\sim 100{ }^{14} \mathrm{C}$ yr $(11,700-9000$ cal BP interval). Larger millennia-scale tropical $\mathrm{R}$ changes further back in time cannot be excluded, but are not very likely given the limited tropical $R$ variability between the end of the Pleistocene and the present.

The globally integrated atmospheric ${ }^{14} \mathrm{C}$ levels, and global $\mathrm{R}$, depend on a globally integrated ocean circulation and ocean-atmospheric exchange rate. To derive global INTCAL98 atmospheric values, we used a constant late-glacial tropical $\mathrm{R}$ value of $500{ }^{14} \mathrm{C}$ yr. Implied in the switch from tropical to global conditions is the notion that tropical $\mathrm{R}$ and global $\mathrm{R}$ parallel each other over the 24,000 11,850 cal BP interval.

The corals discussed so far were formed in the mixed surface layer of the tropical ocean. Deep-sea corals, on the other hand, live mostly between 500 and $2000 \mathrm{~m}$ depth and are not confined to tropical latitudes. These corals exhibit substantial century-scale deepwater R change in the Atlantic $(16,000$ 12,000 cal BP interval: Adkins et al. 1998; Mangini et al. 1998). Atlantic deepwater ${ }^{14} \mathrm{C}$ levels are tied to specific deepwater masses (e.g., Stuiver and Östlund 1980) and the deepwater R changes are most likely caused by shifts in their depths. These relatively fast regional ocean circulation changes have the potential to modify (to an unknown extent) the values of both late-glacial atmospheric ${ }^{14} \mathrm{C}$ and mixed-layer $\mathrm{R}$.

\section{MARINE VARVE CHRONOLOGY}

Marine sediments of the Cariaco Basin in the Atlantic Ocean (at the northern continental margin of Venezuela) yield a ${ }^{14} \mathrm{C}$-varve count sequence (Hughen et al. 1998) useful for INTCAL98 construction. The floating chronology is tied to the absolute time scale by matching marine ${ }^{14} \mathrm{C}$ ages to the INTCAL98 tree-ring data (the tree-ring data are increased by 500 and $400{ }^{14} \mathrm{C}$ yr for, respectively, $12-10$ and $10-8 \mathrm{ka}$ cal BP). The best fit between the ${ }^{14} \mathrm{C}$ ages of the adjusted tree-ring record and the Cariaco Basin is shown in Figure 4. The absolute time scale produced in this manner for the floating varves reduces the Hughen et al. (1998) varve count time scale by 40 yr. The latest tree-ring and $R$ adjustments cause this minor difference. The matching is secure within a statistical error (one $\sigma$ ) of $15 \mathrm{yr}$.

Applying R $=400$ (10-8 ka cal BP) and $500(14.5-10 \mathrm{ka} \mathrm{cal} \mathrm{BP}){ }^{14} \mathrm{C}$ yr to the corals and calibrated varve series yields the Figure 5 "atmospheric" values. Relative to the INTCAL 98 tree-ring record, the varve-derived ${ }^{14} \mathrm{C}$ ages scatter less $(\mathrm{k}=1.3)$ than the coral ${ }^{14} \mathrm{C}$ ages. The observed varve scatter $\sigma$ of $\sim 95{ }^{14} \mathrm{C}$ yr $\left(11,700-9000 \mathrm{cal}\right.$ BP interval) suggests a $\sim 100{ }^{14} \mathrm{C}$ yr limit on tropical $\mathrm{R}$ change on decadal/century time-scales. 


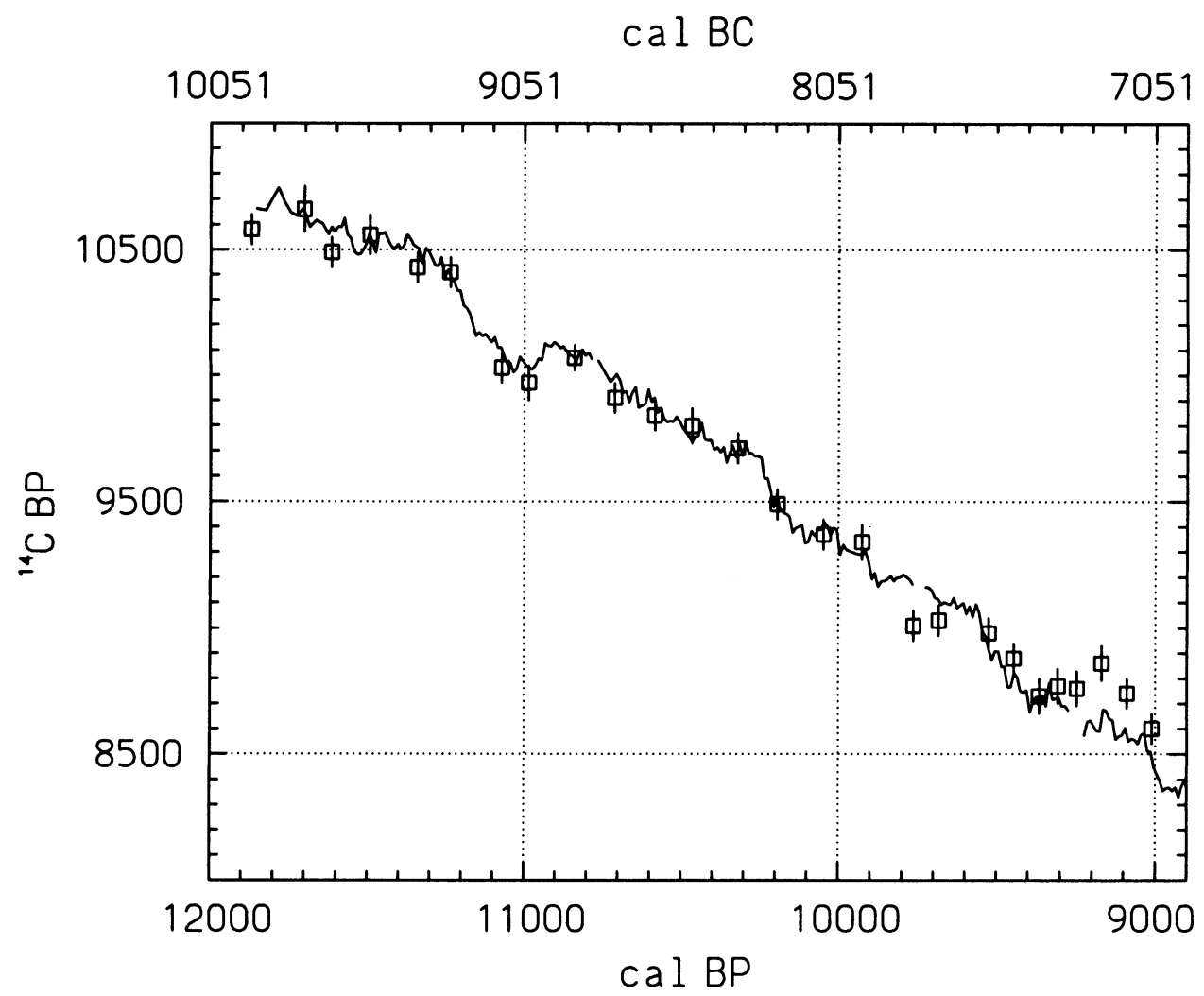

Fig. 4. Cal BP calibration of a floating marine varve record. The varve data given here, and in the following figures, are from Hughen et al. (1998). Shown is the best fit between the marine equivalent of the INTCAL98 tree-ring record (solid line, R values as noted with Fig. 3 were applied) and the measured varve results ( $\square$, with $1 \sigma$ bars).

\section{ATMOSPHERIC AND MARINE INTCAL98 CONSTRUCTION}

The atmospheric INTCAL 98 curve consists of two segments, each derived from diverse materials and techniques. The materials used are wood (tree rings), coral and marine sediment. The ${ }^{14} \mathrm{C}$ activity measurement is common to all but the cal BP time scale determination differs. The wood samples (back to $11,850 \mathrm{cal} \mathrm{BP}$ ) are dated through dendrochronological means, the corals through U-Th determinations, and the marine sediment through ${ }^{14} \mathrm{C}$ matching of (floating) varve and tree-ring chronologies. Marine coral and varve data, normalized on atmospheric levels, yield a $24,000-$ 11,850 cal BP extension of the directly measured atmospheric values. Only two coral measurements are available for the $40,000-24,000 \mathrm{cal}$ yr interval, resulting in rather speculative age "calibration" over this interval.

The $11,850-0$ cal BP segment was constructed from ${ }^{14} \mathrm{C}$ age measurements reported by the Belfast, Heidelberg, Pretoria/Groningen and Seattle laboratories (Stuiver, Reimer and Braziunas 1998; Kromer and Spurk 1998; McCormac et al. 1998a and b; Pearson, Becker and Qua 1993; Vogel and van der Plicht 1993; Kromer et al. 1986). Decadal ${ }^{14} \mathrm{C}$ ages back to $11,614 \mathrm{cal}$ BP were constructed by taking the average ${ }^{14} \mathrm{C}$ age of all samples with cal midpoints within the cal decade. The rationale for this approach can be found in the introduction. The 11,624-11,854 cal BP interval is covered by the measurements of a single laboratory (Heidelberg; Kromer and Spurk 1998) of 20- to 30-yr treering samples. The segments of Figure A8-A19 (Appendix) depict for $1000 \mathrm{cal}$ yr intervals the "dec- 


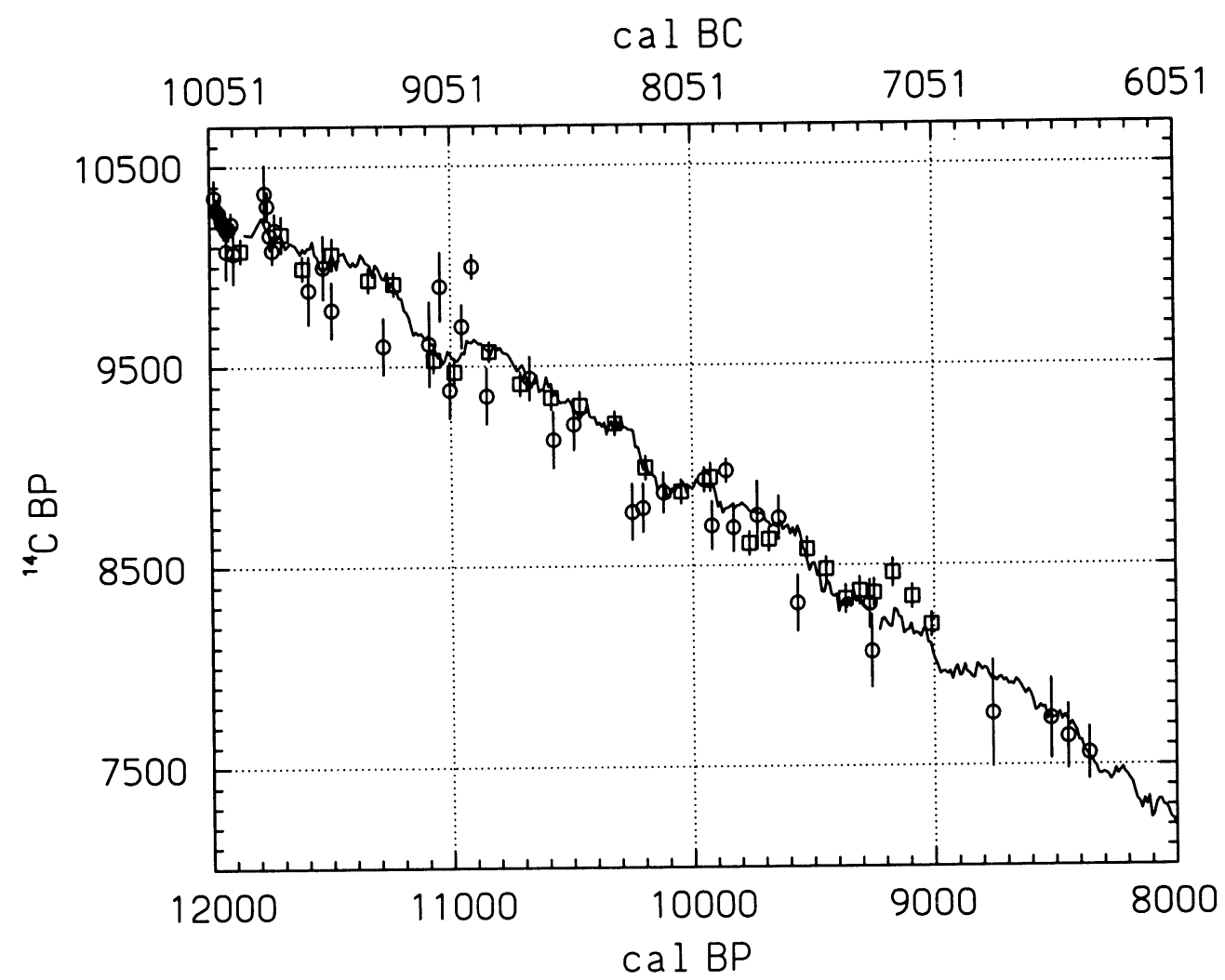

Fig. 5. INTCAL 98 tree-ring ${ }^{14} \mathrm{C}$ ages (solid line) and the atmospheric equivalent (obtained by using the $\mathrm{R}$ values noted with Fig. 3) of 1$)$ coral ${ }^{14} \mathrm{C}$ ages $(0$, bar $=2 \sigma)$ and 2$)$ marine varve ages $(\square$, bar $=1 \sigma)$. The cal BP ages of the corals were determined by U/Th dating and the cal BP ages of the varves by a floating varve count that was shifted to the position given in Fig. 4.

adal" tree-ring derived portion of the atmospheric INTCAL 98 calibration curve (11,854-0 cal BP). The curve was constructed by linearly connecting the ${ }^{14} \mathrm{C}$ ages obtained for the decadal (plus a few bidecadal) cal age intervals. The INTCAL98 standard deviation (width of the calibration curve, not given in Fig. A) resulted from the linear connection of the $\pm 1.3 \sigma$ age errors.

The primary data of the 24,000-11,850 cal BP segment are coral and varve measurements (Bard $e t$ al. 1998; Burr et al. 1998; Edwards et al. 1993; Hughen et al. 1998). The ${ }^{14} \mathrm{C}$ ages of the $12,500-$ $11,850,15,000-12,500,19,500-15,000$, and $24,000-19,500$ cal BP intervals, adjusted to atmospheric levels by deducting a reservoir deficiency of $500{ }^{14} \mathrm{C}$ yr (the rather minor $25{ }^{14} \mathrm{C}$ yr standard deviation was neglected) from the marine ages, are depicted in Figures 6-9 with vertical bars representing $1 \sigma$ in the varve ${ }^{14} \mathrm{C}$ determinations, and $2 \sigma$ for the coral ${ }^{14} \mathrm{C}$ determinations. The "atmospheric" ${ }^{14} \mathrm{C}$ ages of the $40,000-15,000 \mathrm{cal}$ BP interval are given in Figure 10. Coral and varve data coverage is excellent for $16,000-11,850 \mathrm{cal} \mathrm{BP}$, less so for $24,000-16,000 \mathrm{cal} \mathrm{BP}$, and marginal for $40,000-24,000$ cal BP.

The minimum smoothing spline (Reinsch 1967) of Figures 6-9, anchored at the last tree-ring point at $11,854 \mathrm{cal} \mathrm{BP}$, was used to generate the atmospheric INTCAL98 ${ }^{14} \mathrm{C}$ ages of the $11,850-16,000$ cal BP period. Due to the scarcity of coral samples, INTCAL 98 lacks detail between 24,000 and $16,000 \mathrm{cal} \mathrm{BP}$. Here the spline is essentially linear, with cal $\mathrm{BP}=1.15{ }^{14} \mathrm{C} \mathrm{BP}+680$. 


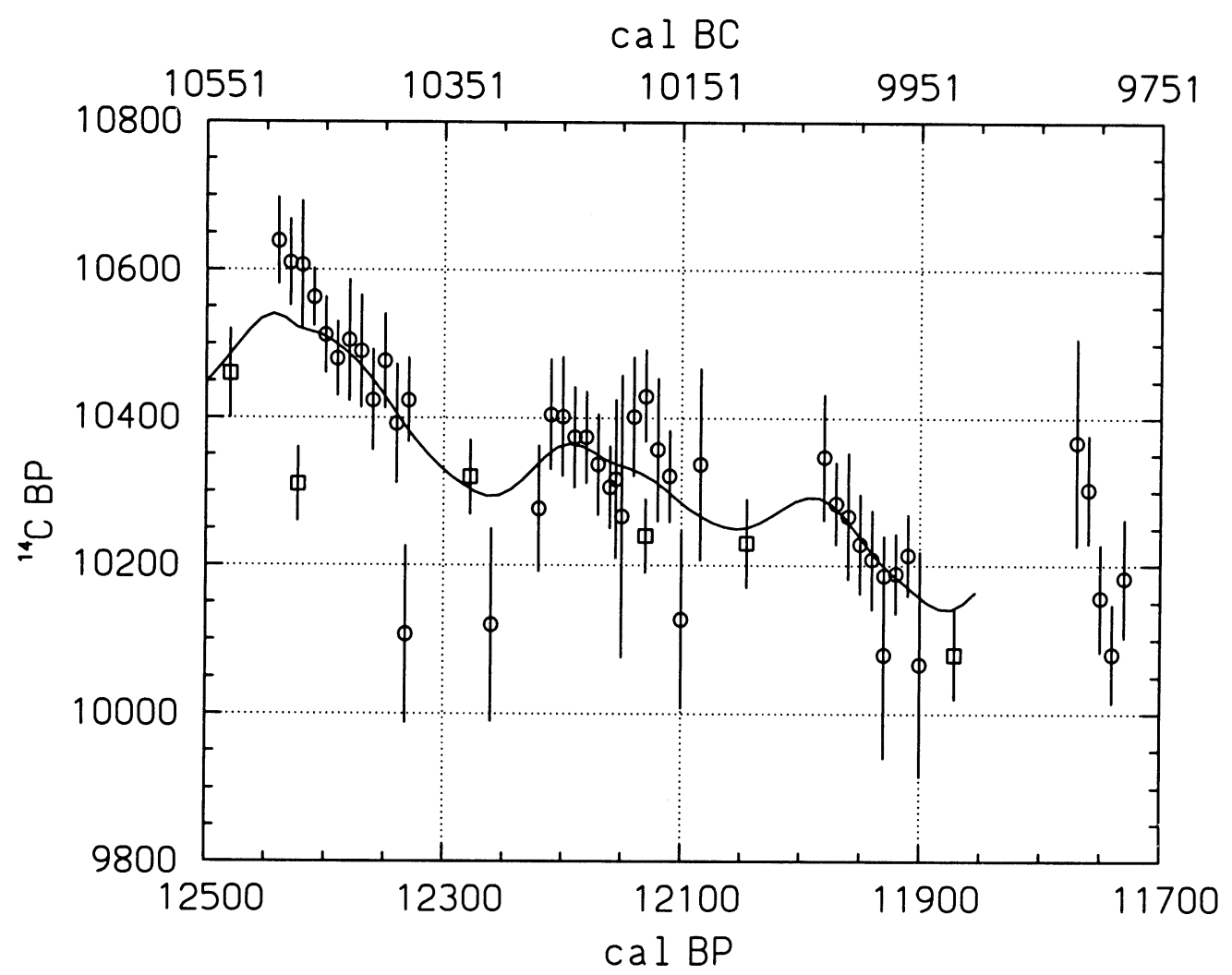

Fig. 6. "Atmospheric" coral $(O$, bar $=2 \sigma)$ and varve $(\square, b a r=1 \sigma){ }^{14} \mathrm{C}$ ages. The minimum smoothing spline (solid line), anchored at the last tree-ring point $(11,854 \mathrm{cal} \mathrm{BP})$, was used to derive the INTCAL $98{ }^{14} \mathrm{C}$ ages of the $12,500-$ 11,854 cal BP time interval.

The 24,000-11,850 cal BP coral- and varve-derived segment of atmospheric INTCAL 98 is part of the Figure A calibration curve. For the marine-derived atmospheric ages we used, as discussed, a spline with minimum smoothing. The INTCAL98 standard deviation (width of the calibration curve) was derived by using a standard deviation of $2 \sigma$ for the coral ${ }^{14} \mathrm{C}$ ages, $1 \sigma$ for the varve ${ }^{14} \mathrm{C}$ ages, and a $\mathrm{k}=1.3$ error multiplier for both $(\sigma=$ standard deviation in the measurement).

There are only two data points between 40,000 and 24,000 cal BP, and a linear relationship is automatic (Fig. 10). This interval, due to the lack of corroborating data points, generates an error-prone calibration curve. The $40,000-24,000 \mathrm{cal}$ BP interval, as a consequence, was not considered for INTCAL98 inclusion.

The conversion of marine ${ }^{14} \mathrm{C}$ age to atmospheric ${ }^{14} \mathrm{C}$ age (by deducting $500{ }^{14} \mathrm{C}$ yr from the marine age) is an approximation only. The marine record also contains less detail than the atmospheric one, especially for cosmic-ray induced ${ }^{14} \mathrm{C}$ production rate change (e.g., Stuiver, Reimer and Braziunas 1998 ). Only the $15,000-12,000 \mathrm{cal}$ BP interval, with a large number of marine data points, produces a century-scale fine structure.

The marine INTCAL98 curve (Fig. B) of the $8800-0$ cal BP interval contains marine ${ }^{14} \mathrm{C}$ ages derived from the tree-ring record via carbon reservoir modeling (Stuiver, Reimer and Braziunas 1998). Coral and marine varve ${ }^{14} \mathrm{C}$ ages were used for the $24,000-8800 \mathrm{cal}$ BP marine INTCAL98 


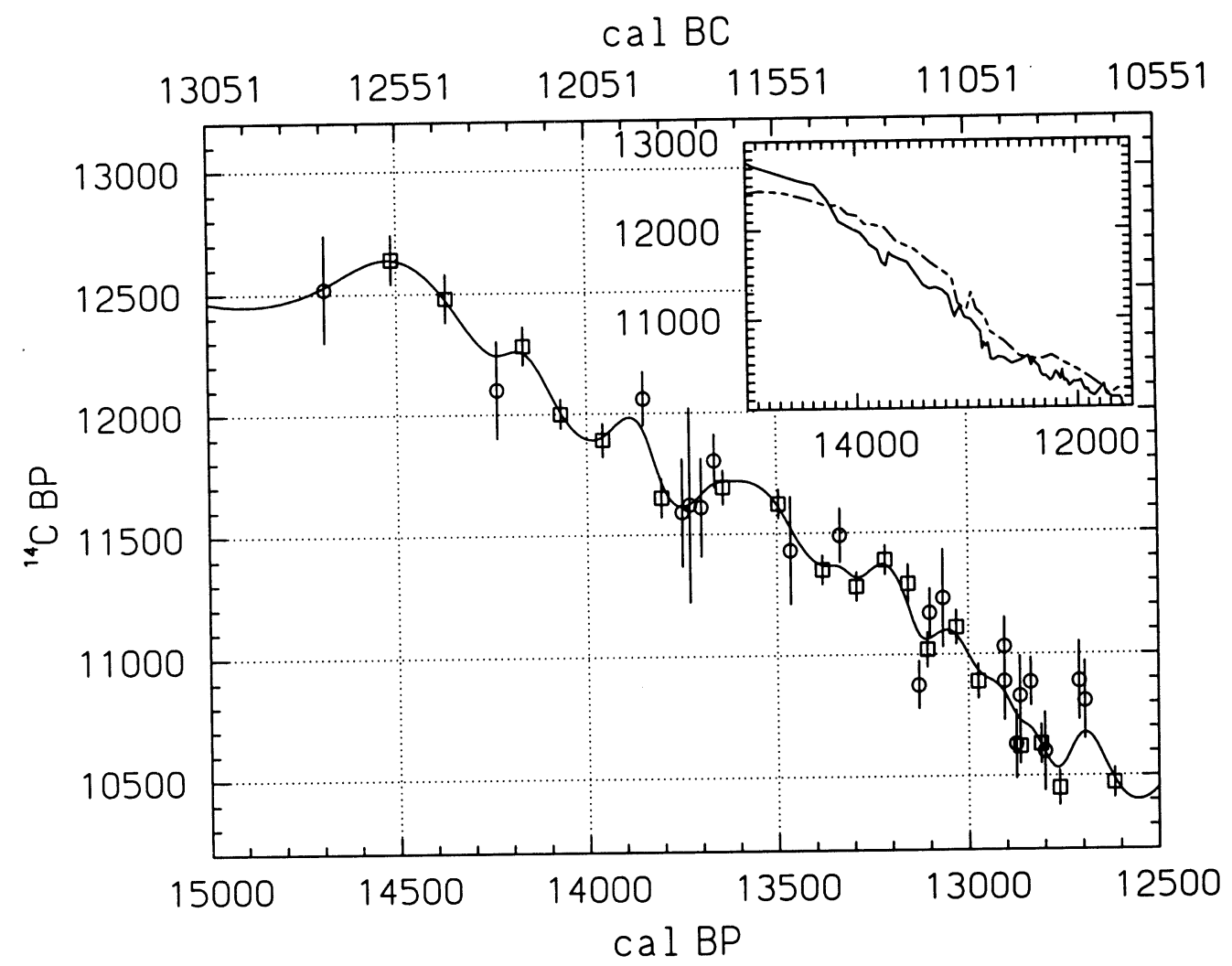

Fig. 7. Splined "atmospheric" coral and varve data 15,000-12,500 cal BP (solid line; see Fig. 6 caption for symbols). The inset compares three-point moving averages of "atmospheric" (marine derived) INTCAL $98{ }^{14} \mathrm{C}$ ages (solid line) to a similar moving average of terrestrial ${ }^{14} \mathrm{C}$ ages (dashed line) dated by varves (Kitagawa and van der Plicht 1998).

segment. Here we splined the available marine ${ }^{14} \mathrm{C}$ dates of the $15,585-8800 \mathrm{cal} \mathrm{BP}$ interval (Figs. 5-7), and used a linear approximation for the 24,000-15,585 cal BP interval (Figs. 8 and 9). The calculated INTCAL98 standard deviation (width of the calibration curve, not given in Fig. A) was derived from the measured $2 \sigma$ deviation for the coral ${ }^{14} \mathrm{C}$ ages, $1 \sigma$ for the varve ${ }^{14} \mathrm{C}$ ages, and a $\mathrm{k}=1.3$ error multiplier for both $(\sigma=$ standard deviation in the measurement). The connection between the splined and carbon reservoir calculated marine ${ }^{14} \mathrm{C}$ ages is depicted in Figure 11.

The INTCAL98 marine calibration curves (Fig. B) reflect global open ocean conditions. Regional departures from the global values can be expressed in a $\Delta \mathrm{R}$ parameter, as discussed in Stuiver, Reimer and Braziunas 1998.

\section{INTCAL98 $\Delta^{14} \mathrm{C}$}

Converting the atmospheric ${ }^{14} \mathrm{C}$ ages into $\Delta^{14} \mathrm{C}$ values yields Figure 12 . The long-term trend in $\Delta^{14} \mathrm{C}$ is usually attributed to geomagnetically induced ${ }^{14} \mathrm{C}$ production rate change.

An interesting $\Delta^{14} \mathrm{C}$ comparison can be made with the recently published $45,000 \mathrm{cal} \mathrm{BP}$ atmospheric varve chronology (Kitagawa and van der Plicht 1998). Although for the 15,000-12,000 cal BP interval the long-term trends of the Kitagawa and van der Plicht atmospheric record and the INTCAL98 atmospheric record derived from marine data are similar, century-scale detail is less fine in the varve 


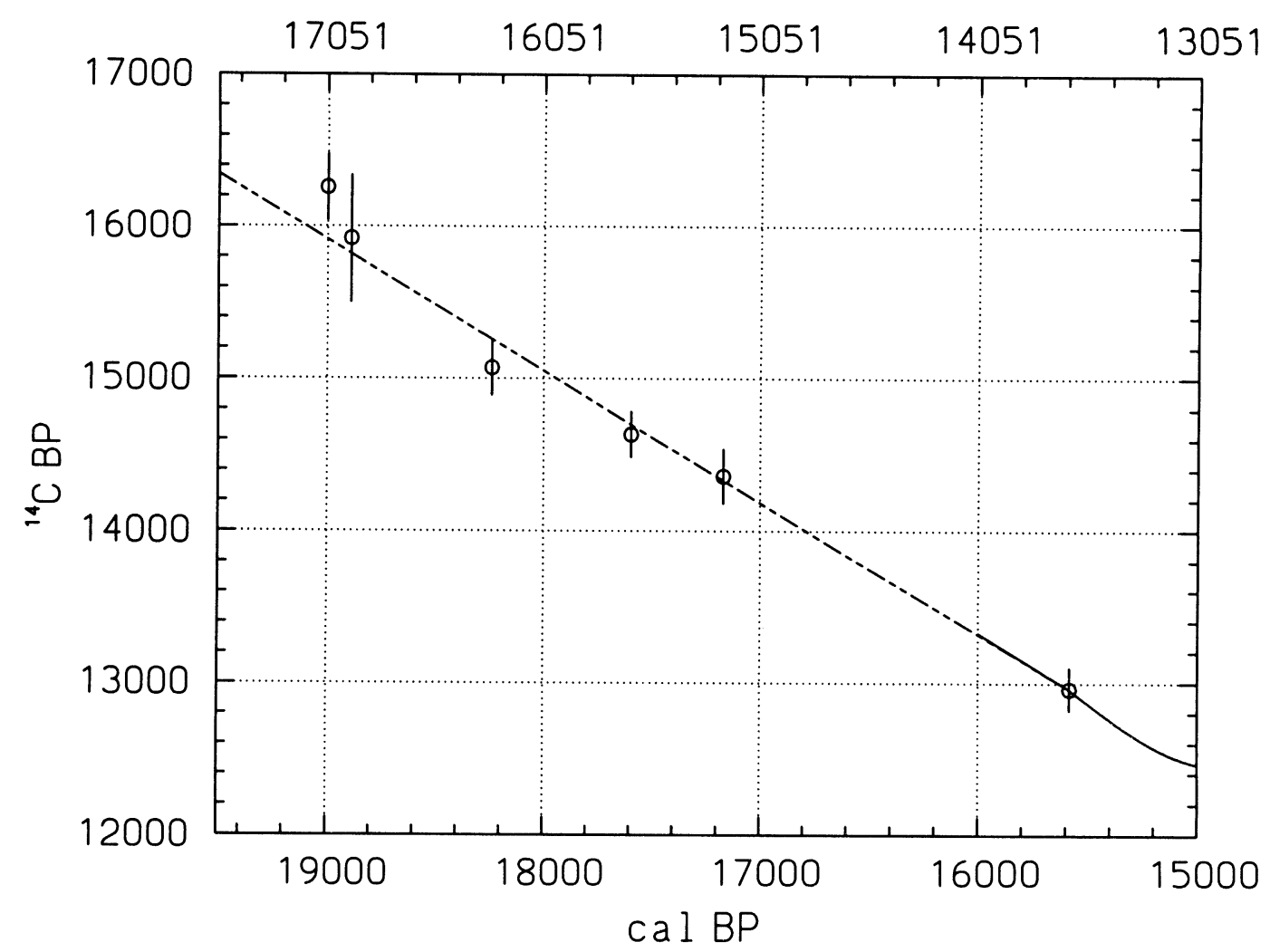

Fig. 8. Splined "atmospheric" coral data (19,500-15,000 cal BP; see Fig. 6 for symbols). The number of data points is too small to generate detail in the dashed curve.

record (the inset in Fig. 7 compares three-point moving averages of both data sets). The varve curve, on the other hand, is more detailed for pre-15,000 cal BP ages where the coral curve (due to the limited number of data points) appears linear.

Given a perfect varve chronology, the 175 -yr offset (Fig. 7 inset) would indicate a marine reservoir correction of $325{ }^{14} \mathrm{C} \mathrm{yr}$ instead of $500{ }^{14} \mathrm{C}$ yr. Because a zero-error varve chronology is unlikely, however, this cannot be definitely concluded.

The century- and millennium-scale $\Delta{ }^{14} \mathrm{C}$ variations (residual $\Delta{ }^{14} \mathrm{C}$, in per mil) of Figure 13 were obtained by deducting a $2000 \mathrm{yr}$ moving average.

Reduced North Atlantic deepwater formation is tied to reduced surface-water transport toward the North (the "warm" Gulf stream), causing Northern regions (e.g., Western Europe and Greenland) to become colder. Reduced deepwater formation is also tied to atmospheric ${ }^{14} \mathrm{C}$ increase. Because lower $\delta^{18} \mathrm{O}$ values ${ }^{9}$ accompany reduced atmospheric precipitation temperatures, one expects an inverse relationship between $\delta^{18} \mathrm{O}$ and $\Delta^{14} \mathrm{C}$ for oceanic-induced climate perturbations. The relationship (correlation coefficient $\mathrm{r}=-0.54, \Delta^{14} \mathrm{C} / \delta^{18} \mathrm{O}=-20.4$ ) is depicted in Figure 14 , where residual INTCAL98 $\Delta^{14} \mathrm{C}$ (U/Th time scale) is compared to inverted $\delta^{18} \mathrm{O}$ (ice layer count time scale) of the GISP2 Greenland ice core (Stuiver, Grootes and Braziunas 1995) for the 15,500-10,500 cal BP interval.

${ }^{9} \delta^{18} \mathrm{O}$ is the per mil deviation of the sample ${ }^{18} \mathrm{O} /{ }^{16} \mathrm{O}$ ratio from that of the SMOW standard . 


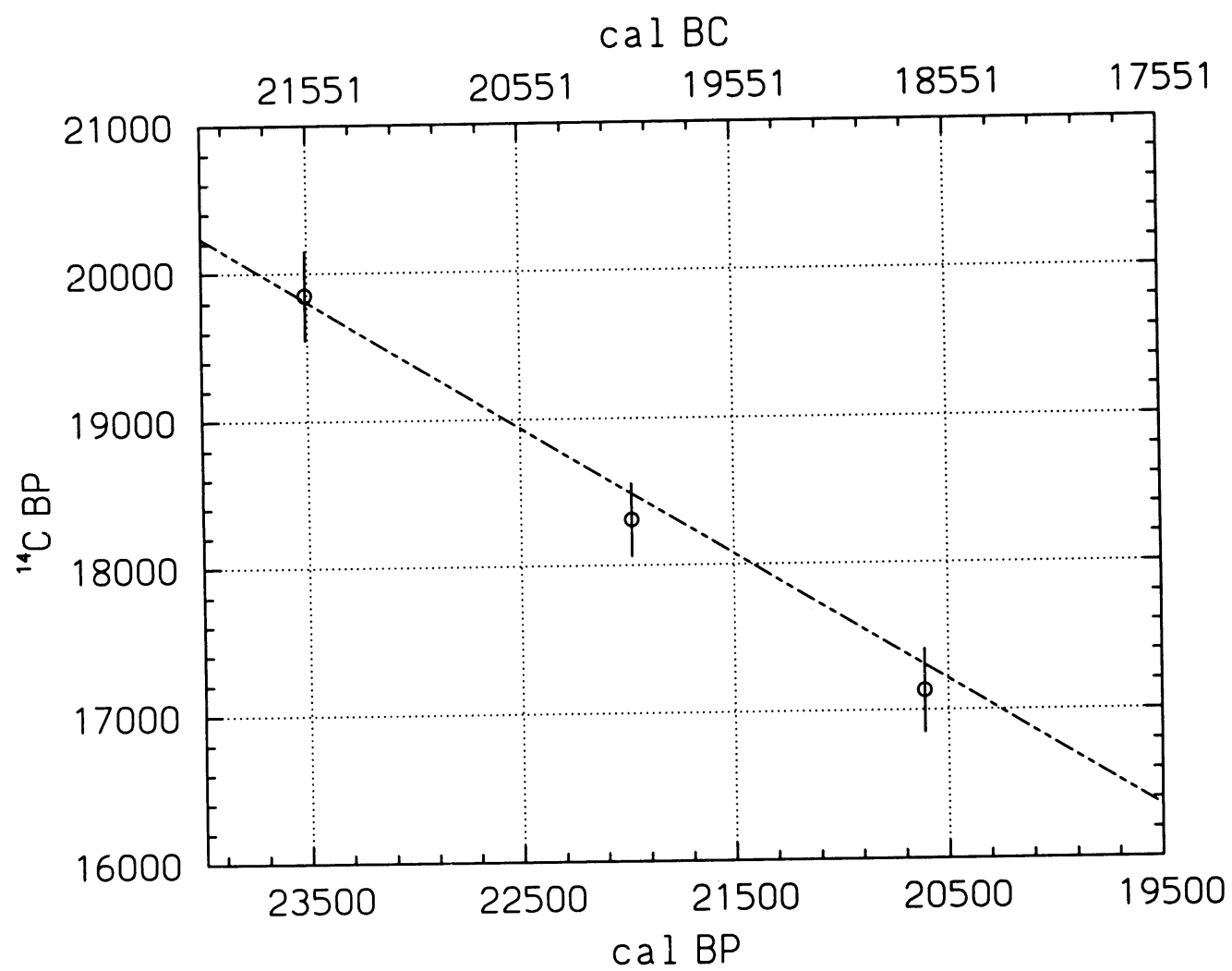

Fig. 9. Splined "atmospheric" coral data $(24,000-19,500$ cal BP; see Fig. 6 for symbols). The number of data points is too small to generate detail in the dashed curve.

The reduction of residual $\Delta^{14} \mathrm{C}$ during the $15,000-14,500$ cal BP interval suggests that the temperature increase of the Bølling (which starts $c a .14,670$ cal BP) is tied to increased deepwater formation. The increase is followed by a two-step reduction and reverses again to increased deepwater formation (Broecker 1997, 1998; Hughen et al. 1998; Stuiver and Braziunas 1993) at the beginning of the Younger Dryas $(\sim 12,890 \mathrm{cal} \mathrm{BP})$. This increase in deepwater formation ultimately leads to the relatively stable temperatures of the Holocene. To complicate matters, a Younger Dryas bipolar seesaw also may be operating (Broecker 1998). The Holocene itself has several century-scale oceanic and solar-induced (the solar connection yields $\Delta^{14} \mathrm{C}=60 \delta^{18} \mathrm{O}$ ) $\Delta^{14} \mathrm{C}$ perturbations (Stuiver and Braziunas 1993; Stuiver et al. 1997).

Oceanic-induced atmospheric $\Delta^{14} \mathrm{C}$ changes $\left(\Delta^{14} \mathrm{C} / \mathrm{yr}\right)$ are caused by ${ }^{14} \mathrm{C}$ exchange rate variations between the mixed layer and deep ocean. For a complete cessation of ${ }^{14} \mathrm{C}$ transfer between mixed layer and deep ocean, the cosmic-ray-produced ${ }^{14} \mathrm{C}$ (global production rate $\mathrm{Q}$ in atoms/yr) will be distributed over a much smaller atmosphere, biosphere and mixed layer (ABM) reservoir. Presentday carbon reservoirs contain ${ }^{14} \mathrm{C}$ totaling $8260 \mathrm{yr}$ of production $(8260 \mathrm{Q})$. The $\mathrm{ABM}$ reservoir contains only $7 \%$ of the total amount of exchangeable carbon (e.g., Lal 1985), or $580 \mathrm{yr}$ of ${ }^{14} \mathrm{C}$ production $(580 \mathrm{Q})$. When completely separated from the deep ocean, the atmospheric ${ }^{14} \mathrm{C}$ level of the $\mathrm{ABM}$ reservoir will double in $\mathrm{ca}$. $650 \mathrm{yr}$ (without radioactive decay the doubling time would be 580 $\mathrm{yr}$ ). Thus the fastest rate of ${ }^{14} \mathrm{C}$ change in the atmosphere will be $\sim 1 \%$ per $7 \mathrm{yr}$ for a hypothetical deep ocean suddenly disconnected from the $\mathrm{ABM}$ reservoir. Rates of change of similar magnitude 


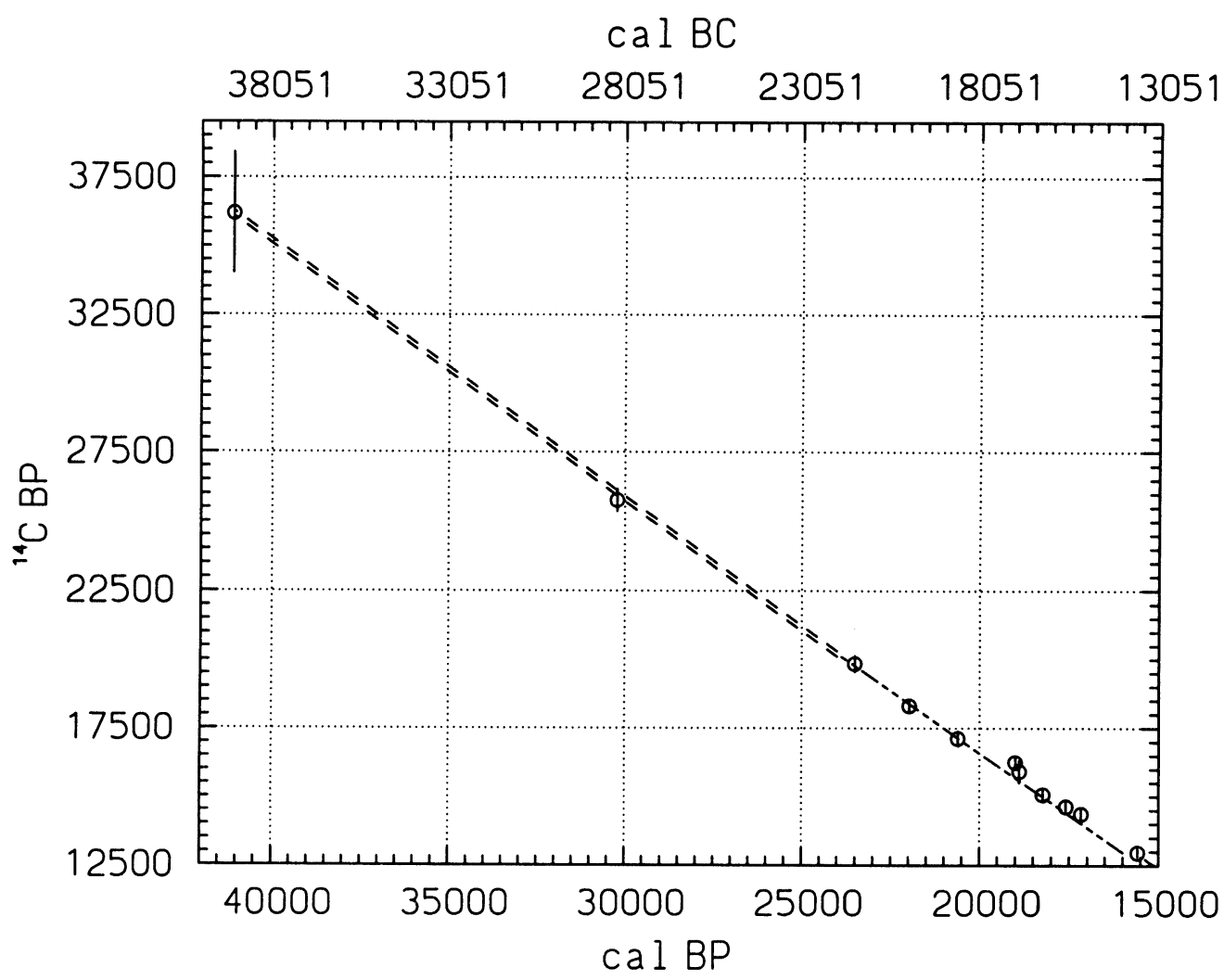

Fig. 10. The extension of the Figs. 6-9 spline to 40,000 cal BP. The double-dashed portion (only two coral measurements) is not acceptable as an INTCAL98 calibration curve.

will occur when fully reconnecting the mixed layer and deep ocean (the downward flux $(0.93 \mathrm{Q})$ is nearly identical to the production rate $\mathrm{Q}$ ).

There are two modes of ${ }^{14} \mathrm{C}$ transport from the mixed layer to the deep ocean. Diffusion (including isopycnal advection) and deepwater formation play a key role. For the Holocene, deepwater formation transports about two-thirds of the global ${ }^{14} \mathrm{C}$ to the deep ocean (Toggweiler, Dixon and Bryan 1989). This yields a maximum $\Delta^{14} \mathrm{C}$ change of $1 \%$ per $10.5 \mathrm{yr}$ for full cessation of deepwater formation alone. The fastest observed century-scale $\Delta^{14} \mathrm{C}$ change of $1 \%$ per $17 \mathrm{yr}$ (near 13810, 13140 and 12720 cal BP, Fig. 14) delivers a $60 \%$ change in the rate of global deepwater formation. The welldefined maxima and minima in Figure 14 also suggest decadal switching times. And fast switching between the two modes of deepwater formation agrees with the symmetrical shape of several century-scale ${ }^{14} \mathrm{C}$ maxima and minima in Figure 14.

The $\Delta^{14} \mathrm{C}$ decline near the start of the Bølling produces a fairly long plateau $(15,000-14,400 \mathrm{cal} \mathrm{BP})$ in the ${ }^{14} \mathrm{C}$ age-cal age relationship (Fig. 7 and 8). There are several Bølling-type oscillations in the GISP2 oxygen isotope record between 40,000 and 15,000 cal BP. Assuming similarity in atmospheric ${ }^{14} \mathrm{C}$ response, one expects $\mathrm{ca} .600$-yr-long ${ }^{14} \mathrm{C}$ age plateaus near $38,400,35,300,33,600$, 32,300 and 29,100 cal BP (GISP2 time scale). 


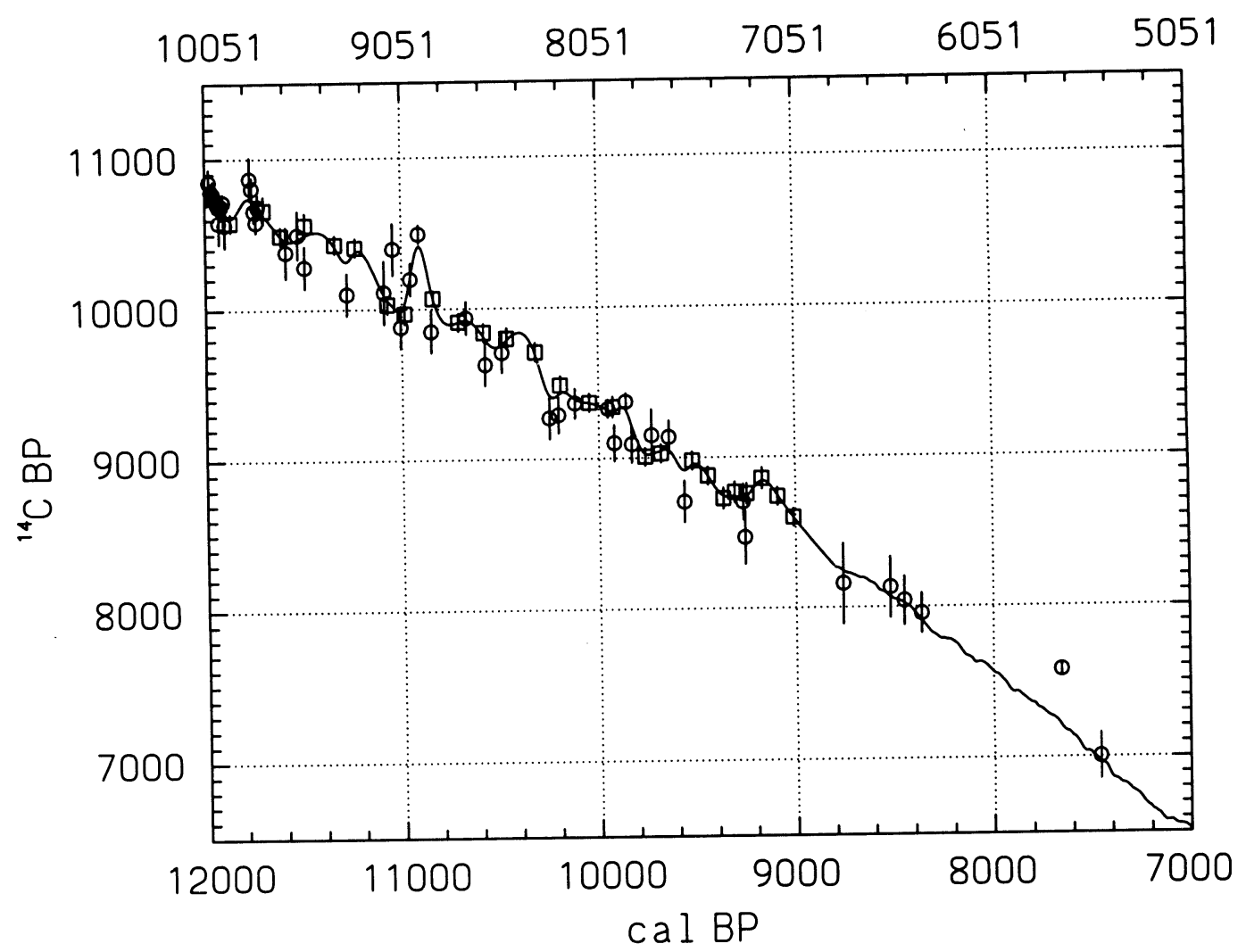

Fig. 11. Coral $(O$, bar $=2 \sigma)$ and varve $(\square$, bar $=1 \sigma){ }^{14} \mathrm{C}$ ages splined (solid line) over the $12,000-8800$ cal BP interval. The spline is connected to the carbon reservoir calculated decadal marine ${ }^{14} \mathrm{C}$ ages (solid line) of the $8800-7000$ cal BP interval. The solid lines form the INTCAL98 calibration curve for marine samples.

\section{Calibration}

It is not possible to suggest guidelines for specific regional (non-hemispheric) offsets due to the lack of precise information on time-dependent regional ${ }^{14} \mathrm{C}$ differences. Offsets (see "Hemispheric and Regional Offsets") introduce uncertainties of one or two decades in the age calibration process of atmospheric samples. Because the ${ }^{14} \mathrm{C}$ level of the Southern Hemisphere is, on average, below that of the Northern Hemisphere, we recommend for Southern Hemispheric samples a ${ }^{14} \mathrm{C}$ age reduction of $24 \pm 3{ }^{14} \mathrm{C}$ yr prior to calibration (pre- AD 1900 atmospheric samples only).

As noted previously, the atmospheric calibration curve is based on 1) a linear connection of the treering generated decadal data points $(11,850-0 \mathrm{cal} \mathrm{BP})$ and 2$)$ a spline with minimum smoothing of reservoir-corrected coral and varve data $(24,000-11,850 \mathrm{cal} \mathrm{BP})$.

The marine calibration curve consists of 1) a linear connection of carbon reservoir calculated decadal marine ages ( $8800-0 \mathrm{cal} \mathrm{BP})$ and a 2$)$ a spline of measured coral and varve ages $(24,000-8800$ cal BP) with a degree of smoothing similar to the atmospheric calibration curve.

The standard deviation in the curves is not drawn in Figures A (atmospheric) and B (marine). For the tree-ring based portion of the atmospheric curve, the width of the curve (the one standard deviation includes a 1.3 error multiplier) starts with an average $9 \mathrm{yr}$ for the youngest millennium and increases 


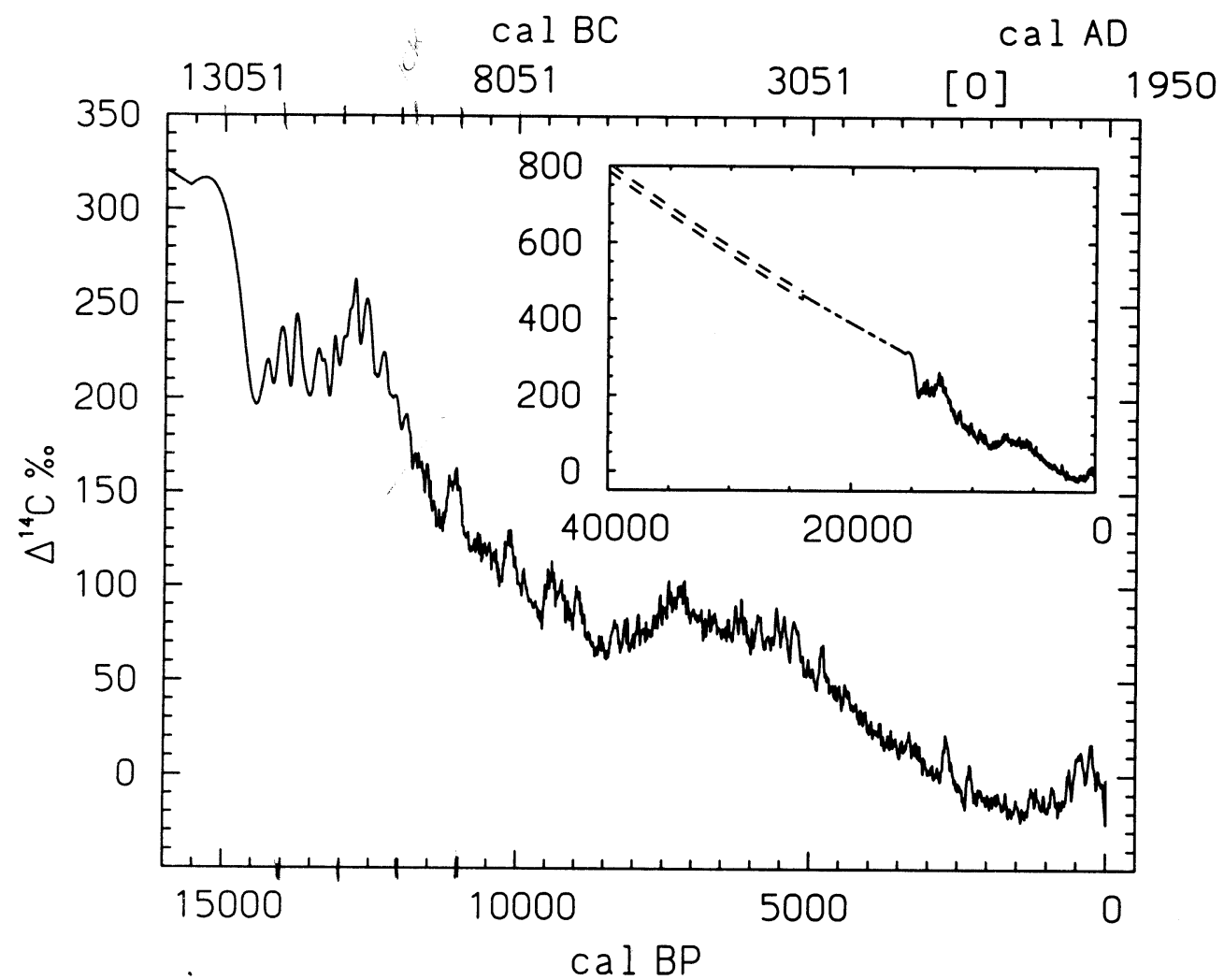

Fig. 12. Atmospheric $\Delta^{14} \mathrm{C}$ profile for 1) $15,500-0$ cal BP and 2) $40,000-0$ cal BP (inset, with $\Delta^{14} \mathrm{C}$ per mil scale). Treering data were used for the $11,854-0 \mathrm{cal} \mathrm{BP}$ construction and marine (coral and varve) information for the remaining part. The solid line represents $\Delta{ }^{14} \mathrm{C}$ values derived from the INTCAL98 ${ }^{14} \mathrm{C}$ age-cal age relationship; the dashed portion is based on the splining of a limited number of data points (see Figs. 7 and 8 ). The double dashed curve is based on only two measurements.

to $23 \mathrm{yr}$ for the older part $(11,000-10,000$ cal BP). The width of the spline, derived from the coral and varve ${ }^{14} \mathrm{C}$ age errors, is one standard deviation (as discussed, we use for the calculation of the actual standard deviation $2 \sigma$ for the coral ${ }^{14} \mathrm{C}$ ages, $1 \sigma$ for the varve ${ }^{14} \mathrm{C}$ ages, and a $\mathrm{k}=1.3$ error multiplier for both) and ranges from an average $100{ }^{14} \mathrm{C}$ yr for the $13,000-12,000$ cal BP interval to $300{ }^{14} \mathrm{C} \mathrm{yr}$ for the 24,000-20,000 cal BP interval.

In its simplest form, the calibration process is a straightforward reading of the calibration curves (Stuiver and Pearson 1993). Because Figures A and B lack uncertainty estimates, we recommend the use of computer programs that include the error margin for age calibration. Computer programs (e.g., CALIB, Stuiver and Reimer 1993; cal15, van der Plicht 1993; and OxCal v2.18, Bronk Ramsey 1994) also generate additional information, such as probability distributions $v s$. cal age. To avoid confusion, we recommend that all computer programs, as of 1999, incorporate the INTCAL98 database for marine and terrestrial age calibration. The INTCAL98 calibration data (atmospheric as well as marine, with one standard deviation uncertainty), the atmospheric $\Delta^{14} \mathrm{C}$ and residual $\Delta^{14} \mathrm{C}$ values, the CALIB 4.0 computer program based on INTCAL98 data, and $\delta^{18} \mathrm{O}$ of the GISP2 ice core can be downloaded from the Quaternary Isotope Laboratory web site at <http://depts.washington.edu/qil/>. 


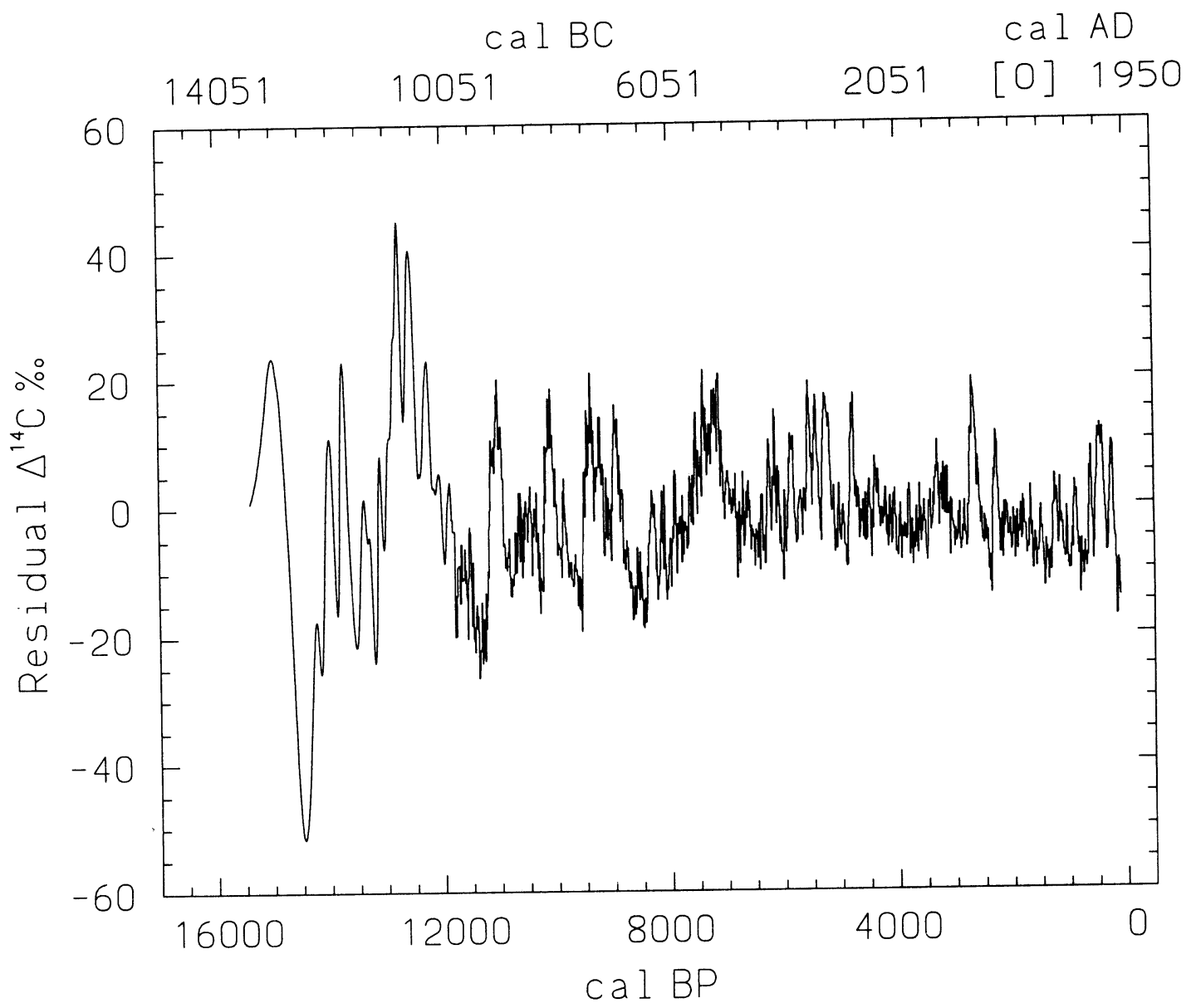

Fig. 13. $\Delta^{14} \mathrm{C}$ residual variations, after removing a 2000 -yr moving average from the Fig. 12 profile

\section{ACKNOWLEDGMENTS}

Both the above radiocarbon age synthesis, and the radiocarbon age measurement program of the Seattle laboratory, were funded by the National Science Foundation (NSF) grant ATM-9310121 to M. Stuiver. Research of E. Bard was supported by IUF, CNRS and EC grants; J. W. Beck and G. S. Burr's research was supported by grants OCE-9402693, OCE-9500647, OCE-9501580, OCE9503256, EAR-9508413, EAR-8904987, EAR-9512334, EAR-9406183, ATM-8922114 (all NSF), NOAA(NAS6QP0381), and ORSTOM. Cariaco basin research (K. O. Hughen) was funded by the U.S. Department of Energy (contract W-7405-ENG-48), a NASA Earth System Science Fellowship, OCE-9521058 (NSF), and NOAA. Heidelberg radiocarbon research (B. Kromer) was funded by the German Science Foundation (DFG) and the Ministry of Science and Research (BMBF). Support for the Belfast laboratory (G. McCormac) was through NERC, grant GR9/02597. The dendrochronological research at Hohenheim (M. Spurk) was supported by the European Commission (ENV4CT95-0127-PL951087) and BMF 07VKV/01A -21178.3/3. 


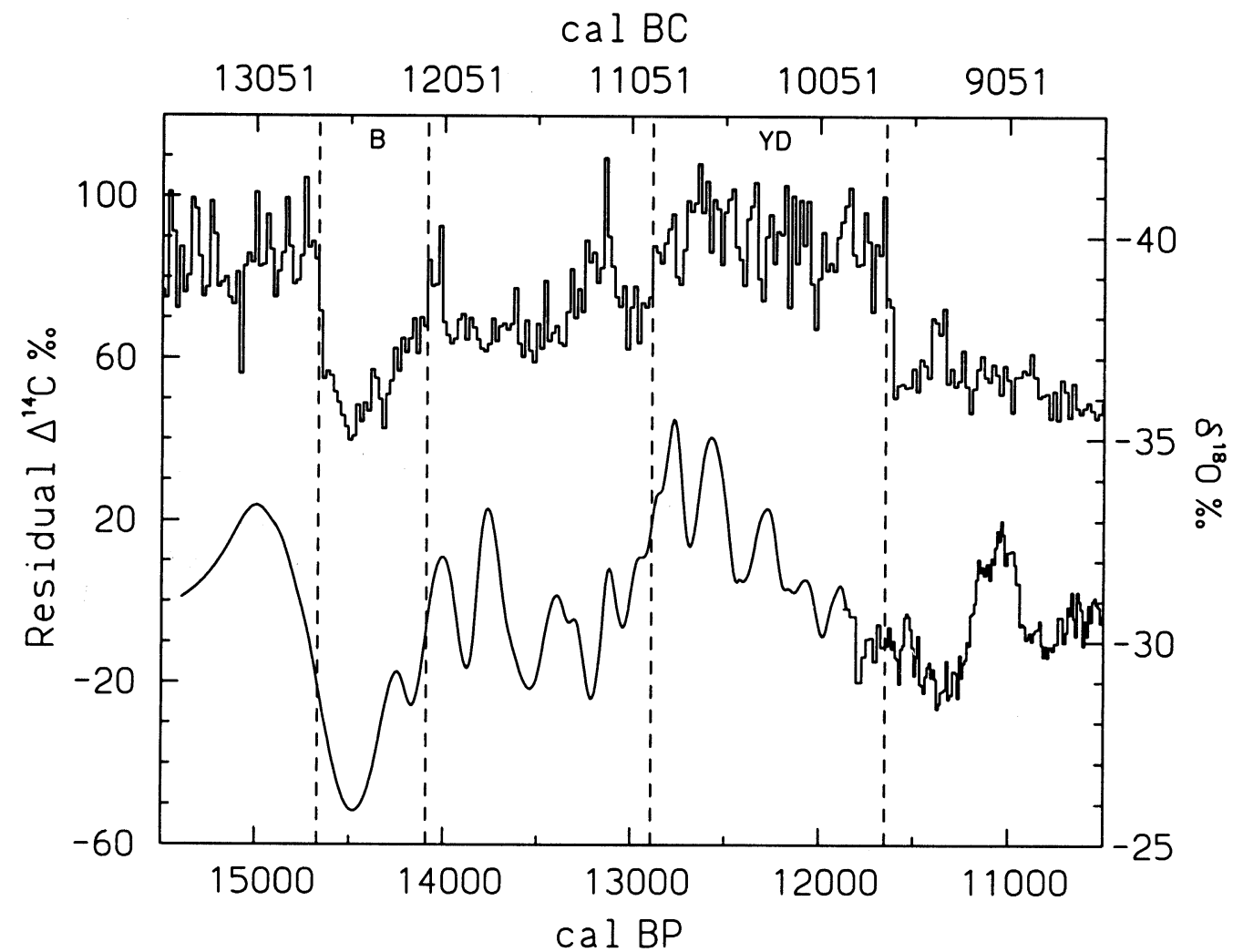

Fig. 14. The upper curve depicts the inverted GISP2 oxygen isotope ratio $\left(\delta^{18} \mathrm{O}\right)$ record with bidecadal time separation (Stuiver, Grootes and Braziunas 1995). The lower curve is based on INTCAL98 residual $\Delta^{14} \mathrm{C}$. The cal BP scale of the oxygen isotope record is based on ice layer counts (Alley et al. 1997). B = Bølling, YD = Younger Dryas.

\section{REFERENCES}

Adkins, J. F., Cheng, H., Boyle, E. A., Druffel, E. R. M. and Edwards, R. L. 1998 Deep-sea coral evidence for rapid change in ventilation of the deep North Atlantic 15,400 years ago. Science 280: 725-728.

Alley, R. B., Shuman, C. A., Meese, D. A., Gow, A. J. Taylor, K. C., Cuffey, K. M., Fitzpatrick, J. J., Grootes, P. M., Zielinski, G. A., Ram, M., Spinelli, G. and Elder, B. 1997 Visual-stratigraphic dating of the GISP2 core: Basis, reproducibility, and application. Journal of Geophysical Research 102(C12): 26,370-26,381.

Bard, E. 1988 Correction of accelerator mass spectrometry ${ }^{14} \mathrm{C}$ ages measured in planktonic foraminifera: $\mathrm{Pa}$ leoceanographic implications. Paleoceanography 3: 635-645.

Bard, E., Arnold, M., Hamelin, B., Tisnerat-Laborde, N. and Cabioch, G. 1998 Radiocarbon calibration by means of mass spectrometric ${ }^{230} \mathrm{Th} /{ }^{234} \mathrm{U}$ and ${ }^{14} \mathrm{C}$ ages of corals: An updated database including samples from Barbados, Mururoa and Tahiti. Radiocarbon, this issue.

Bard, E., Arnold, M., Mangerud, M., Paterne, M., Labey- rie, L., Duprat, J., Mélières, M. A., Sonstegaard, E. and Duplessy, J. C. 1994 The North Atlantic atmosphere-sea surface ${ }^{14} \mathrm{C}$ gradient during the Younger Dryas climatic event. Earth and Planetary Science Letters 126: 275-287.

Bard, E., Hamelin, B., Fairbanks, R. G. and Zindler, A. 1990 Calibration of the ${ }^{14} \mathrm{C}$ timescale over the past 30,000 years using mass spectrometric U-Th ages from Barbados corals. Nature 345: 405-410.

Braziunas, T. F., Fung, I. E. and Stuiver, M. 1995 The preindustrial atmospheric ${ }^{14} \mathrm{CO}_{2}$ latitudinal gradient as related to exchanges among atmospheric, oceanic, and terrestrial reservoirs. Global Biogeochemical $C y$ cles 9: 565-584.

Broecker, W. S. 1997 Thermohaline circulation, the Achilles heel of our climate system: Will man-made $\mathrm{CO}_{2}$ upset the current balance? Science 278: 15821588.

1998 Paleocean circulation during the last glaciation: A bipolar seesaw? Paleoceanography 13: 119121. 
Bronk Ramsey, C. 1994 Analysis of chronological information and radiocarbon calibration: The program OxCal. Archaeological and Computing Newsletter 41: 11-16.

Burr, G. S., Beck, J. W., Taylor, F. W., Récy, J., Edwards, R. L. Cabioch, G., Corrège, T., Donahue, D. J. and O'Malley, J. M. 1998 A high-resolution radiocarbon calibration between 11,700 and 12,400 calendar years BP derived from ${ }^{230} \mathrm{Th}$ ages of corals from Espiritu Santo Island, Vanuatu. Radiocarbon, this issue.

Damon, P. E. 1995 A note concerning "Location-dependent differences in the ${ }^{14} \mathrm{C}$ content of wood" by McCormac et al. In Cook, G. T., Harkness, D. D., Miller, B. F. and Scott, E. M., eds., Proceedings of the 15th International ${ }^{14} \mathrm{C}$ Conference. Radiocarbon 37(2): 829830.

Damon, P. E., Burr, G., Peristykh, A. N., Jacoby, G. C. and D'Arrigo, R. D. 1996 Regional radiocarbon effect due to thawing of frozen earth. Radiocarbon 38(3): 597-602.

Edwards, R. L., Beck, J. W., Burr, G. S., Donahue, D. J., Chappell, J. M. A., Bloom, A. L., Druffel, E. R. M. and Taylor, F. W. 1993 A large drop in atmospheric ${ }^{14} \mathrm{C} /$ ${ }^{12} \mathrm{C}$ and reduced melting in the Younger Dryas, documented with ${ }^{230} \mathrm{Th}$ ages of corals. Science 260: $962-$ 968.

Hughen, K. A., Overpeck, J. T., Lehman, S. J., Kashgarian, M., Southon, J., Peterson, L. C., Alley, R. and Sigman, D. M. 1998 Deglacial changes in ocean circulation from an extended radiocarbon calibration. Nature 391: 65-68.

Kitagawa, H. and van der Plicht, J. 1998 Atmospheric radiocarbon calibration to 45,000 yr B.P.: Late Glacial fluctuations and cosmogenic isotope production. Science 279: 1187-1190.

Kromer, B., Rhein, M., Bruns, M., Schoch-Fischer, H., Münnich, K. O., Stuiver, M. and Becker, B. 1986 Radiocarbon calibration data for the 6th to the 8th millennia BC. In Stuiver, M. and Kra, R., eds., Calibration Issue. Radiocarbon 28(2B): 954-960.

Kromer, B. and Spurk, M. 1998 Revision and tentative extension of the tree-ring based ${ }^{14} \mathrm{C}$ calibration, 9200 11,855 cal BP. Radiocarbon, this issue.

Lal, D. 1985 Carbon cycle variations during the past 50.000 years: Atmospheric ${ }^{14} \mathrm{C} /{ }^{12} \mathrm{C}$ ratio as an isotopic indicator. In Sundquist, E. T. and Broecker, W. S., eds., The Carbon Cycle and Atmospheric $\mathrm{CO}_{2}$ : Natural Variations, Archean to Present. Geophysical Monograph 32. Washington, D.C., American Geophysical Union: 221-233.

Mangini, A., Lomitschka, M., Eichstädter, R., Frank, N. and Vogler, S. 1998 Coral provides way to age deep water. Nature 392: 347-348.

McCormac, F. G., Baillie, M. G. L., Pilcher, J. R. and Kalin, R. M. 1995 Location-dependent differences in the ${ }^{14} \mathrm{C}$ content of wood. In Cook, G. T., Harkness, D. D., Miller, B. F. and Scott, E. M., eds., Proceedings of the 15th International ${ }^{14} \mathrm{C}$ Conference. Radiocarbon 37(2): 395-407.

McCormac, F. G., Hogg, A. G., Higham, T. F. G., Baillie, M. G. L., Palmer, J. G., Xiong, L., Pilcher, J. R., Brown, D. and Hoper, S. T. 1998a Variations of radiocarbon in tree rings: Southern Hemisphere offset preliminary results. Radiocarbon, this issue.

McCormac, F. G., Hogg, A. G., Higham, T. F. G., LynchStieglitz, J., Broecker, W. S., Baillie, M. G. L., Palmer, J., Xiong, L., Pilcher, J. R., Brown, D. and Hoper S. T. $1998 \mathrm{~b}$ Temporal variation in the interhemispheric ${ }^{14} \mathrm{C}$ offset. Geophysical Research Letters 25: 1321-1324.

Pearson, G. W., Becker, B. and Qua, F. 1993 High-precision ${ }^{14} \mathrm{C}$ measurement of German and Irish oaks to show the natural ${ }^{14} \mathrm{C}$ variations from 7890 to $5000 \mathrm{BC}$. In Stuiver, M., Long, A. and Kra, R. S., eds., Calibration 1993. Radiocarbon 35(1): 93-104.

Pearson, G. W. and Stuiver, M. 1993 High-precision bidecadal calibration of the radiocarbon time scale, 500-2500 BC. In Stuiver, M., Long, A. and Kra, R. S., eds., Calibration 1993. Radiocarbon 35(1): 25-33.

Pilcher, J. R., Baillie, M. G. L., Schmidt, B. and Becker, B. 1984 A 7,272-year tree-ring chronology for Western Europe. Nature 312: 150-152.

Reinsch, C. H. 1967 Smoothing by spline functions. $\mathrm{Nu}$ merische Mathematik 10: 177-183.

Spurk, M., Friedrich, M., Hofmann, J., Remmele, S., Frenzel, B., Leuschner, H. H. and Kromer, B. 1998 Revisions and extension of the Hohenheim oak and pine chronologies: New evidence about the timing of the Younger Dryas / Preboreal transition. Radiocarbon, this issue.

Stuiver, M. 1982 A high-precision calibration of the AD radiocarbon time scale. Radiocarbon 24(1): 1-26.

Stuiver, M. and Becker, B. 1986 High-precision decadal calibration of the radiocarbon time scale, AD 19502500 BC. In Stuiver, M. and Kra, R., eds., Calibration Issue. Radiocarbon 28(2B): 863-910.

1993 High-precision decadal calibration of the radiocarbon time scale, AD 1950-6000 BC. In Stuiver, M., Long, A. and Kra, R. S., eds., Calibration 1993. Radiocarbon 35(1): 35-65.

Stuiver, M. and Braziunas, T. F. 1993 Sun, ocean, climate and atmospheric ${ }^{14} \mathrm{CO}_{2}$ : An evaluation of causal and spectral relationships. The Holocene 3: 289-305.

1998 Anthropogenic and solar components of hemispheric ${ }^{14} \mathrm{C}$. Geophysical Research Letters 25 : 329-332.

Stuiver, M., Braziunas, T. F., Grootes, P. M. and Zielinski, G. A. 1997 Is there evidence for solar forcing of climate in the GISP2 oxygen isotope record? Quaternary Research 48: 259-266.

Stuiver, M., Grootes, P. M. and Braziunas, T. F. 1995 The GISP2 $\delta^{18} \mathrm{O}$ climate record of the past 16,500 years and the role of the sun, ocean, and volcanoes. Quaternary Research 44: 341-354.

Stuiver, M. and Kra, R., eds. 1986 Calibration issue. $R a$ - 
diocarbon 28(2B): 805-1030.

Stuiver, M., Long, A. and Kra, R. S., eds. 1993 Calibration 1993. Radiocarbon 35(1): 1-244.

Stuiver, M. and Östlund, H. G. 1980 GEOSECS Atlantic radiocarbon. Radiocarbon 22(1): 1-24.

Stuiver, M. and Pearson, G. W. 1993 High-precision bidecadal calibration of the radiocarbon time scale, $\mathrm{AD}$ 1950-500 BC and 2500-6000 BC. In Stuiver, M., Long, A. and Kra, R. S., eds., Calibration 1993. Radiocarbon 35(1): 1-23.

Stuiver, M. and Polach, H. A. 1977 Discussion: Reporting of ${ }^{14} \mathrm{C}$ data. Radiocarbon 19(3): 355-363.

Stuiver, M. and Quay, P. D. 1981 Atmospheric ${ }^{14} \mathrm{C}$ changes resulting from fossil fuel $\mathrm{CO}_{2}$ release and cosmic ray flux variability. Earth and Planetary Science Letters 53: 349-362.

Stuiver, M. and Reimer, P. J. 1993 Extended ${ }^{14} \mathrm{C}$ data base and revised CALIB $3.0{ }^{14} \mathrm{C}$ age calibration program. In Stuiver, M., Long, A. and Kra, R. S., eds., Calibration 1993. Radiocarbon 35(1): 215-230.
Stuiver, M., Reimer, P. J. and Braziunas, T. F. 1998 Highprecision radiocarbon age calibration for terrestrial and marine samples. Radiocarbon, this issue.

Toggweiler, J. R., Dixon, K. and Bryan K. 1989 Simulations of radiocarbon in a coarse-resolution world ocean model 1. Steady-state prebomb distributions. Journal of Geophysical Research 94: 8217-8242.

van der Plicht, J. 1993 The Groningen radiocarbon calibration program. In Stuiver, M., Long, A. and Kra, R. S., eds., Calibration 1993. Radiocarbon 35(1): 231237.

Vogel, J. C., Fuls, A., Visser, E. and Becker, B. 1993 Pretoria calibration curve for short-lived samples, 19303350 BC. In Stuiver, M., Long, A. and Kra, R. S., eds., Calibration 1993. Radiocarbon 35(1): 73-85.

Vogel, J. C. and van der Plicht, J. 1993 Calibration curve for short-lived samples, 1900-3900 BC. In Stuiver, M., Long, A. and Kra, R. S., eds., Calibration 1993. Radiocarbon 35(1): 87-91. 


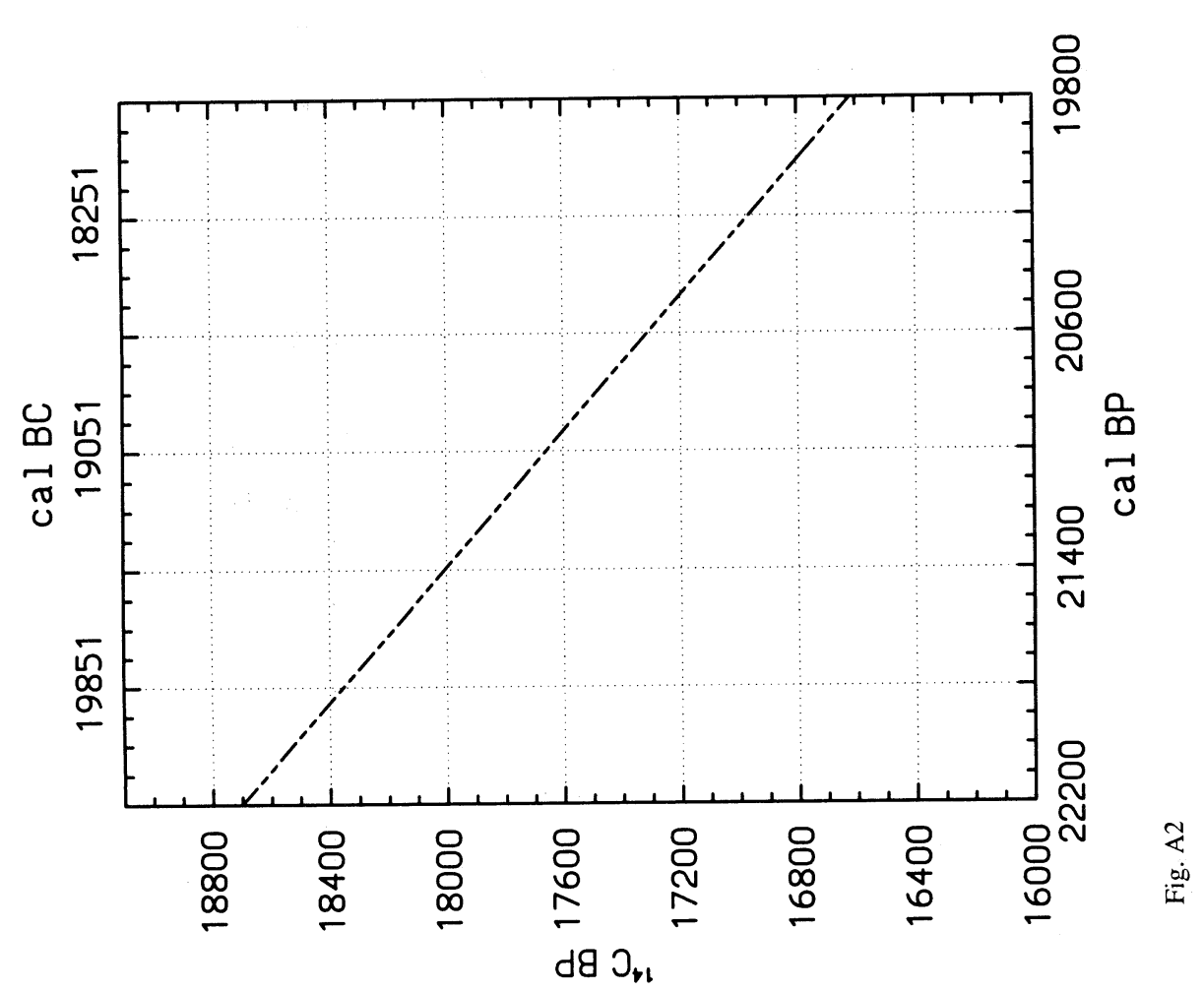

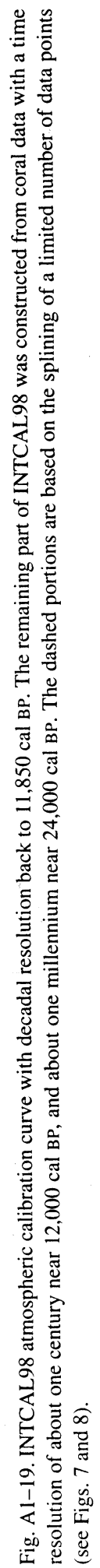



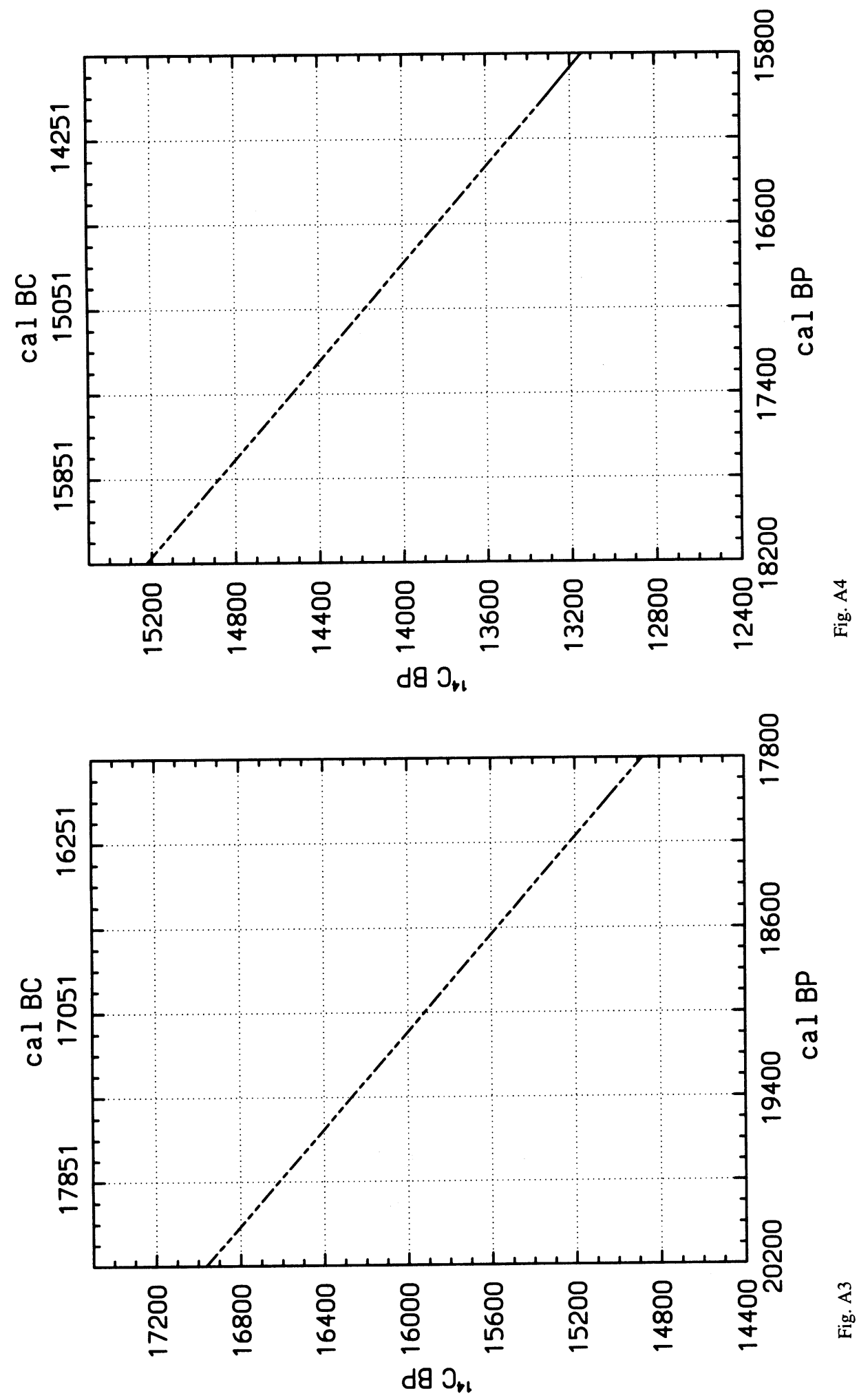

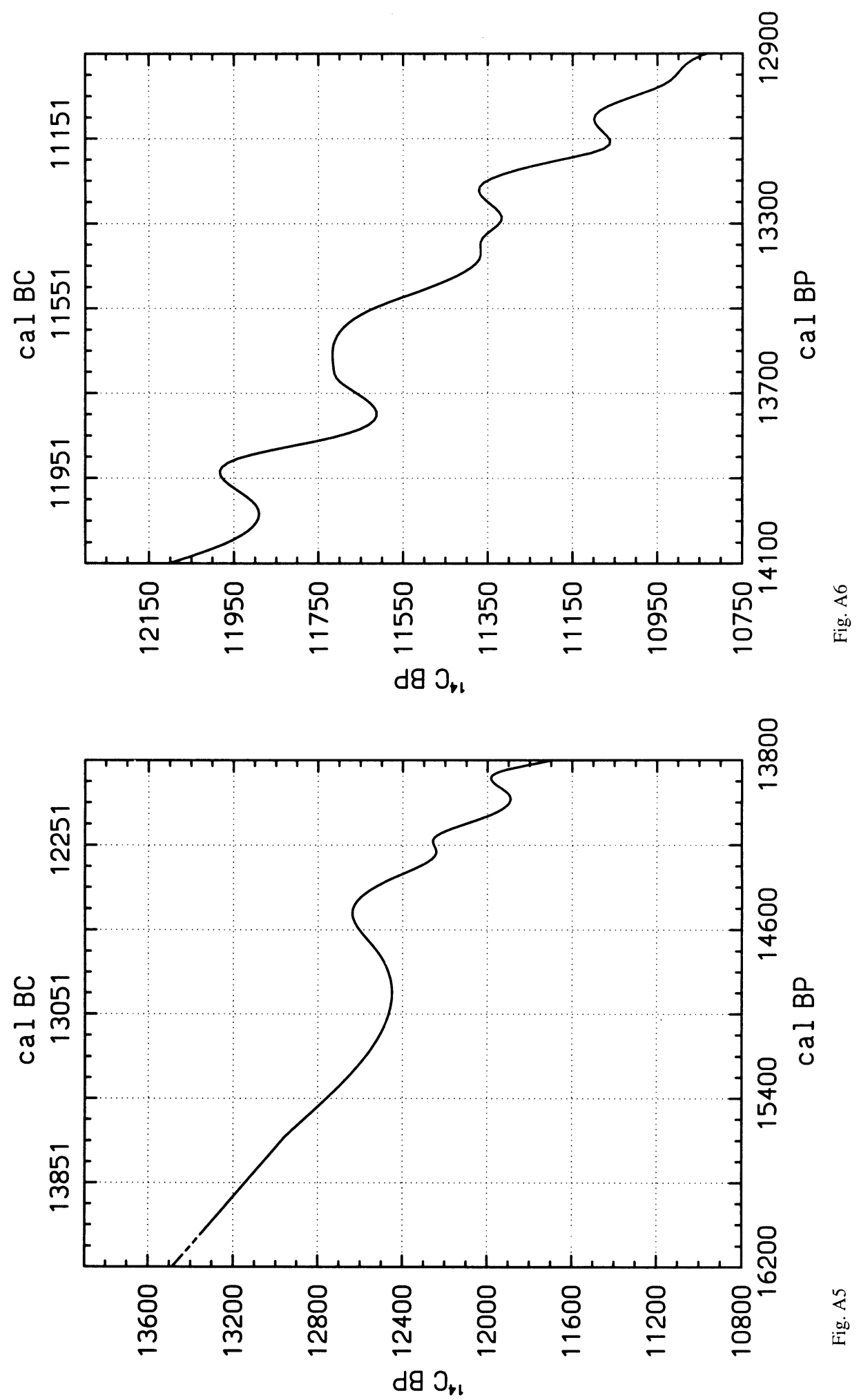

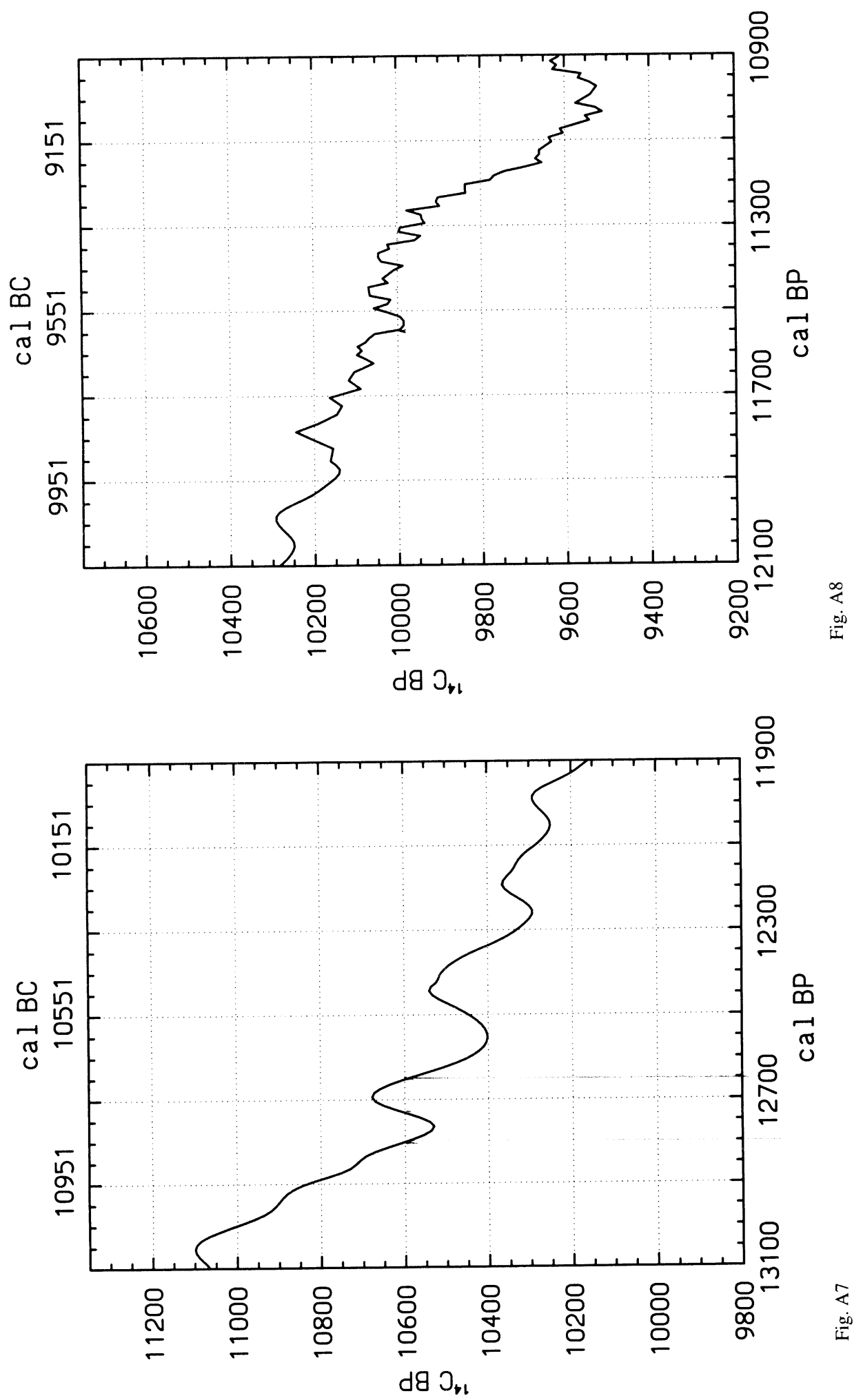

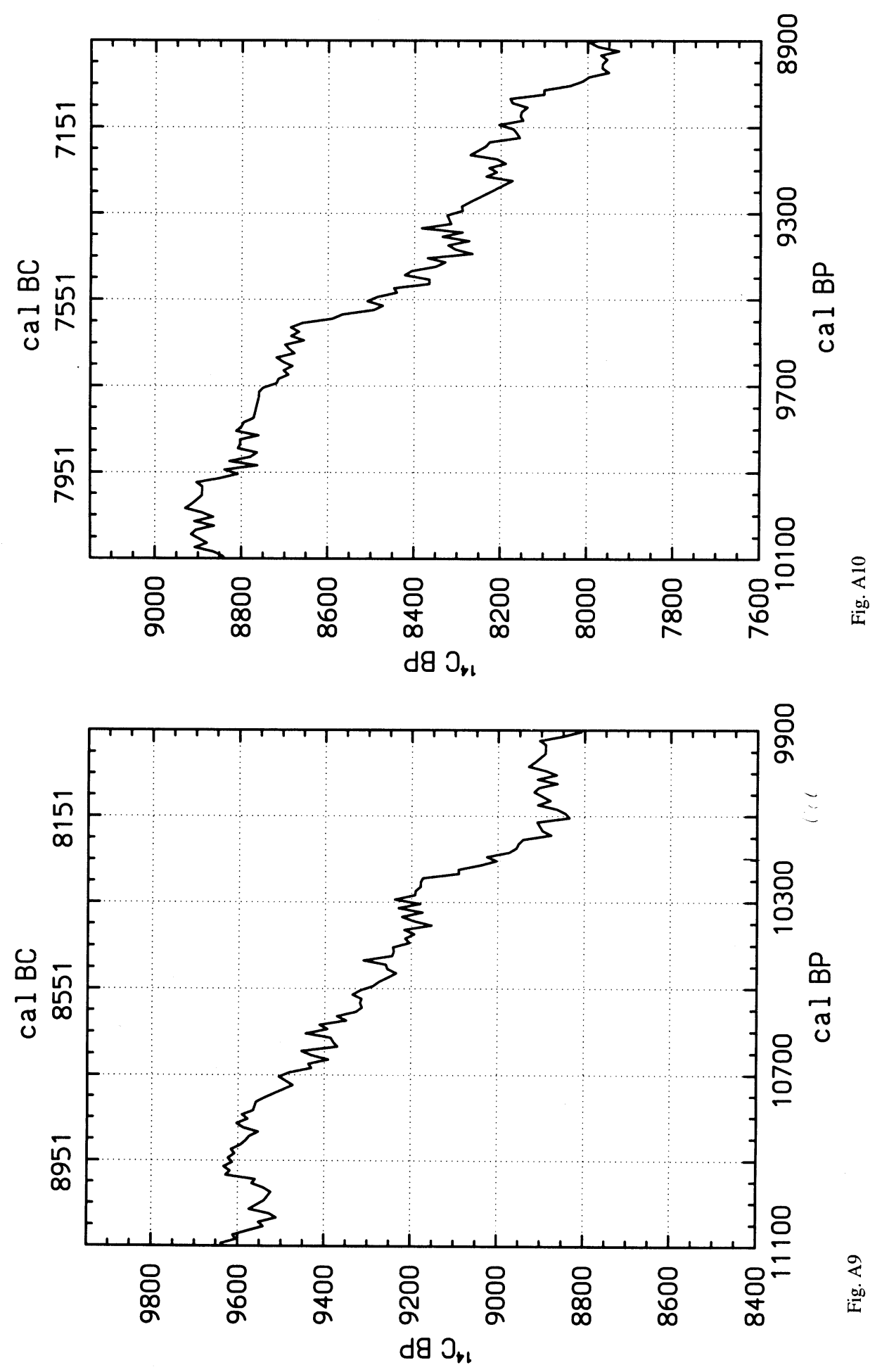

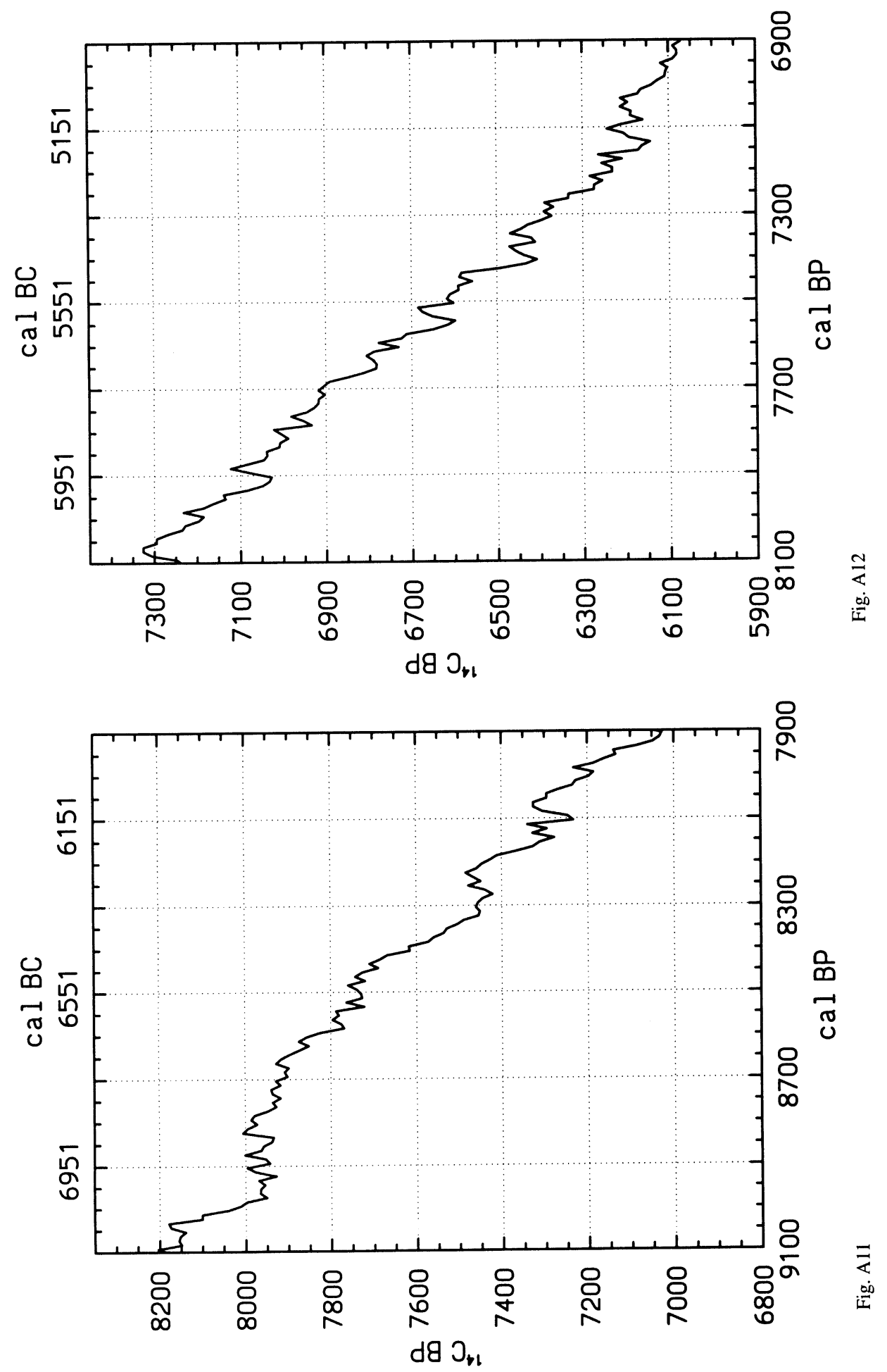

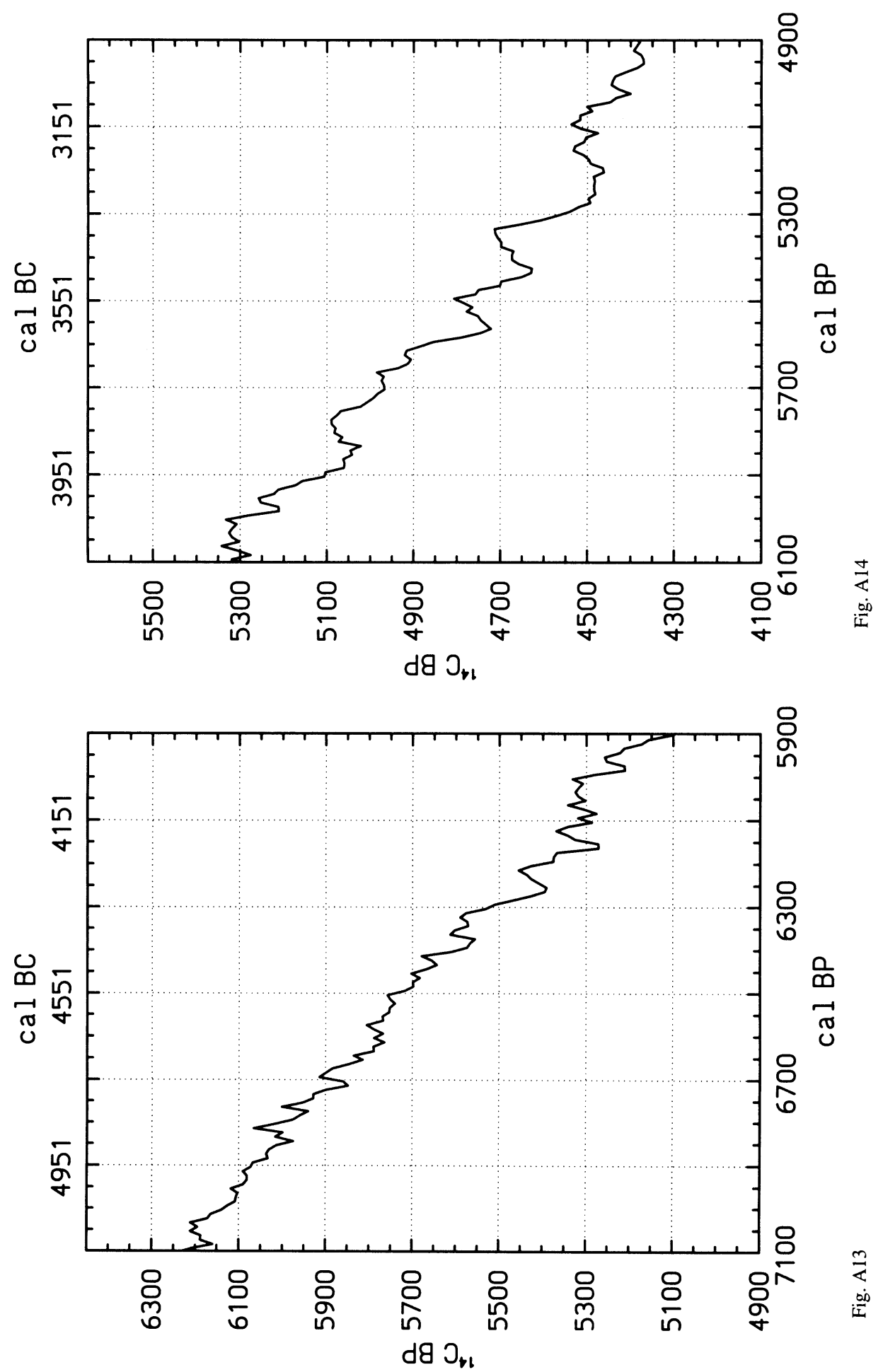

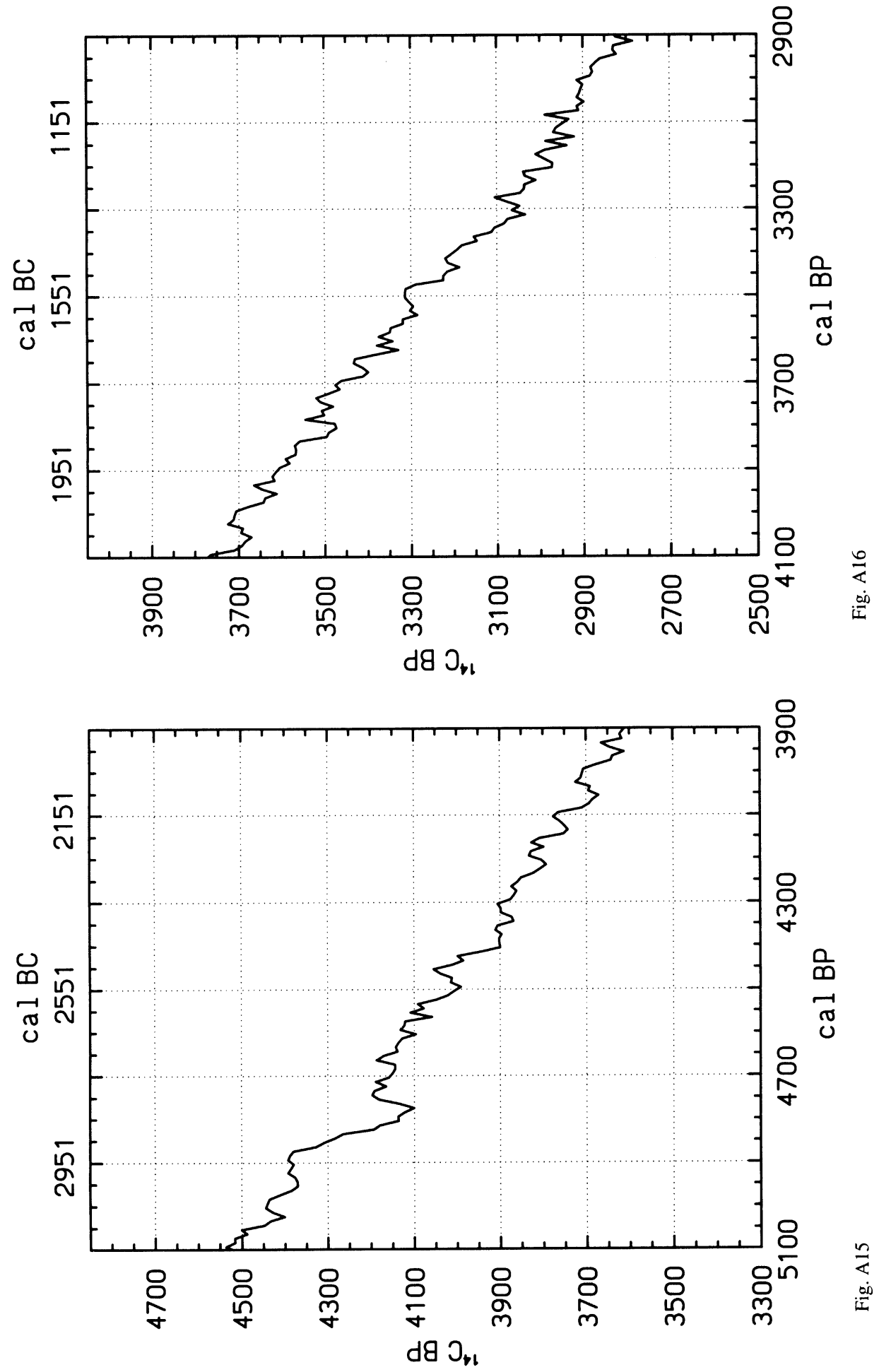

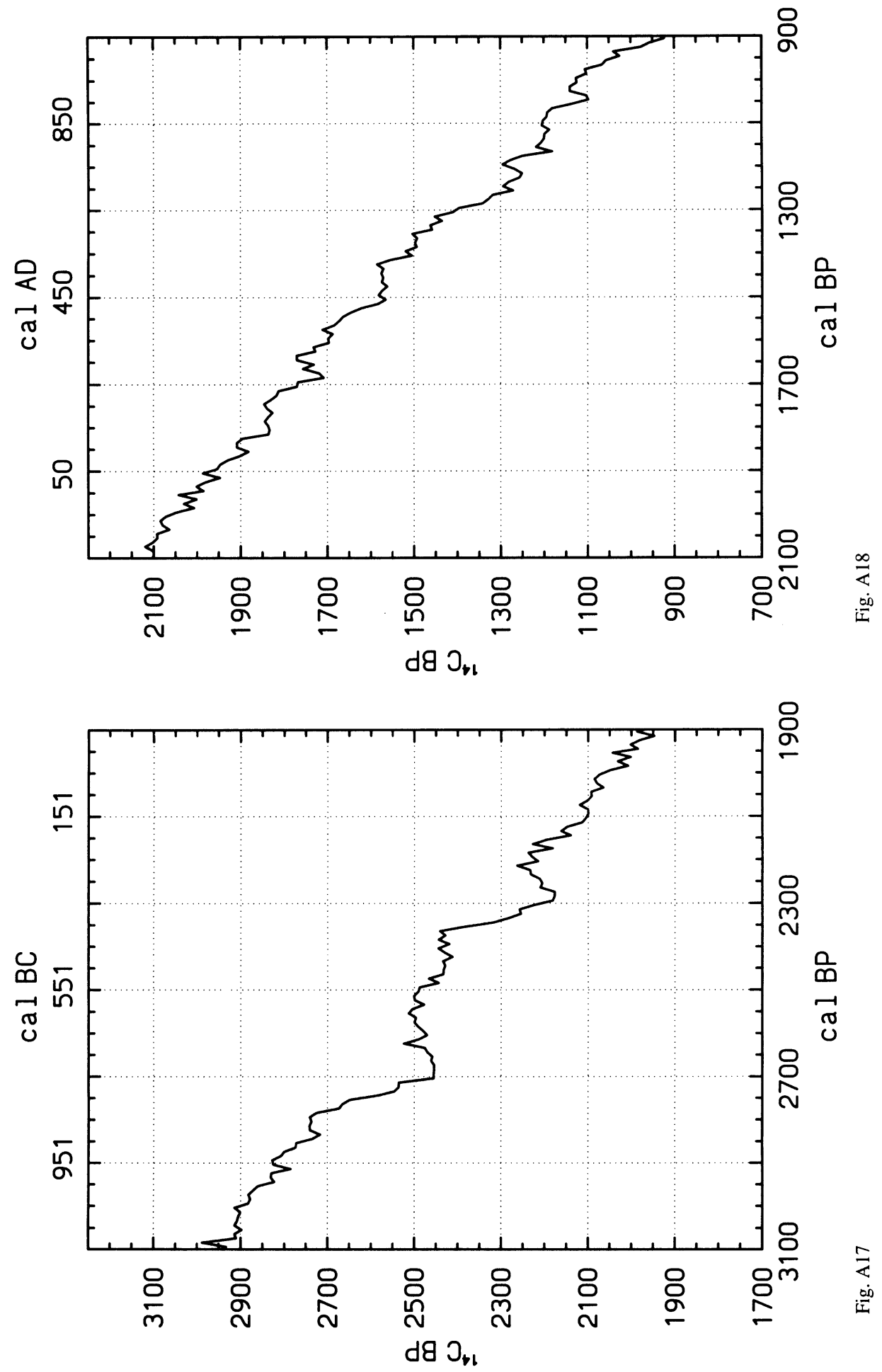


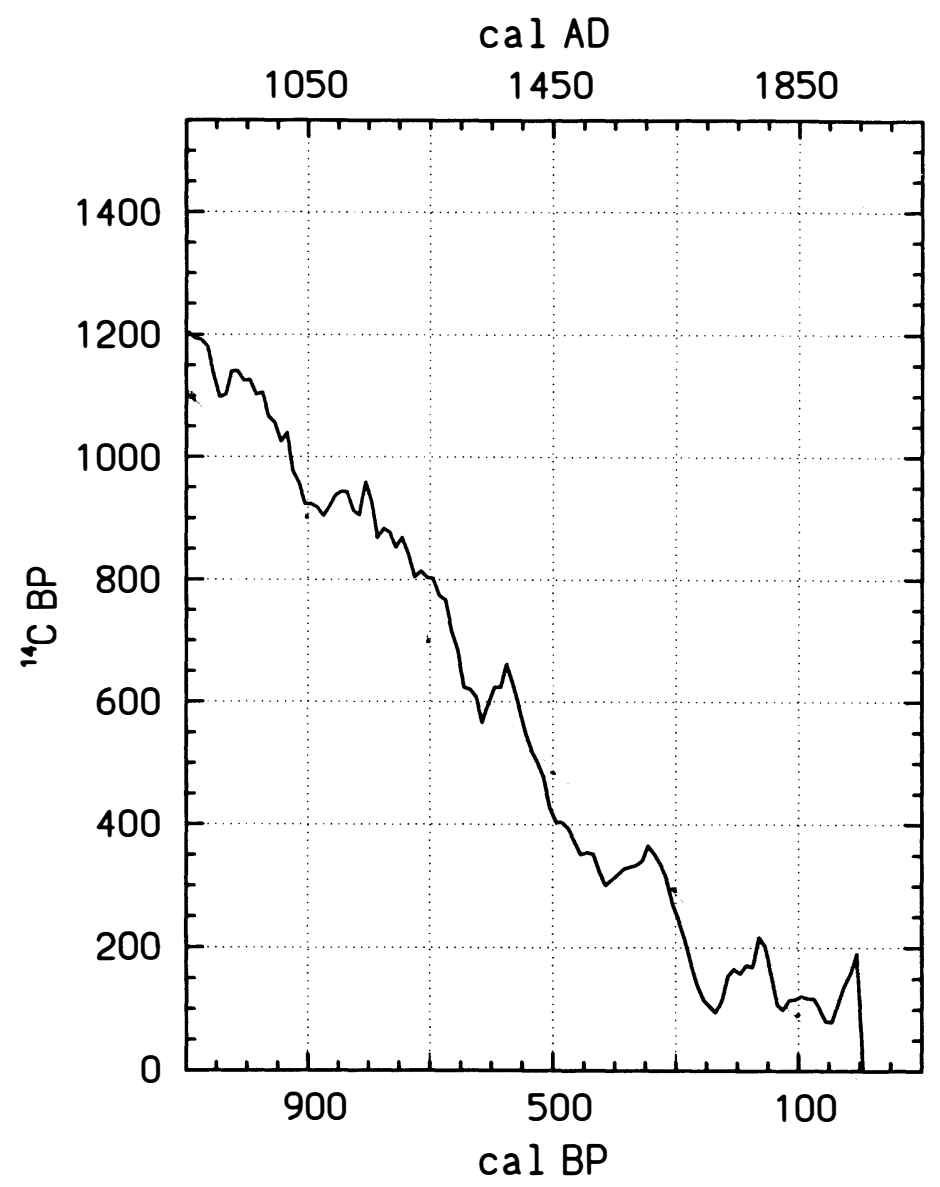

Fig. A19 


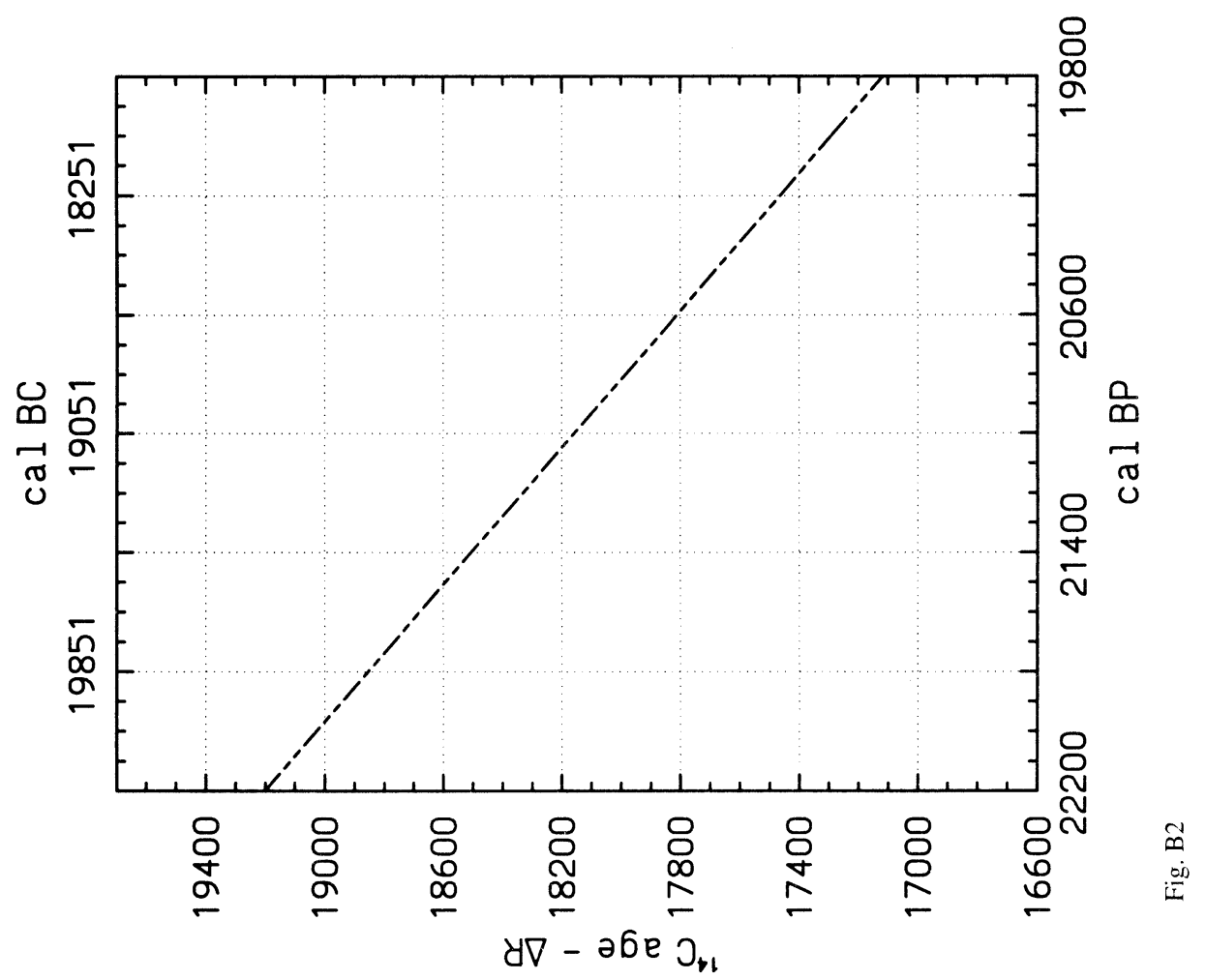

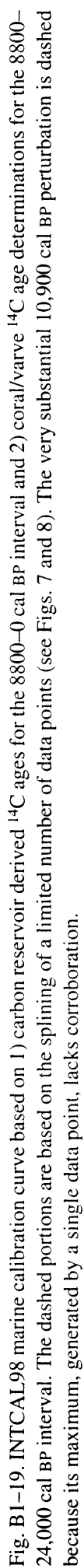

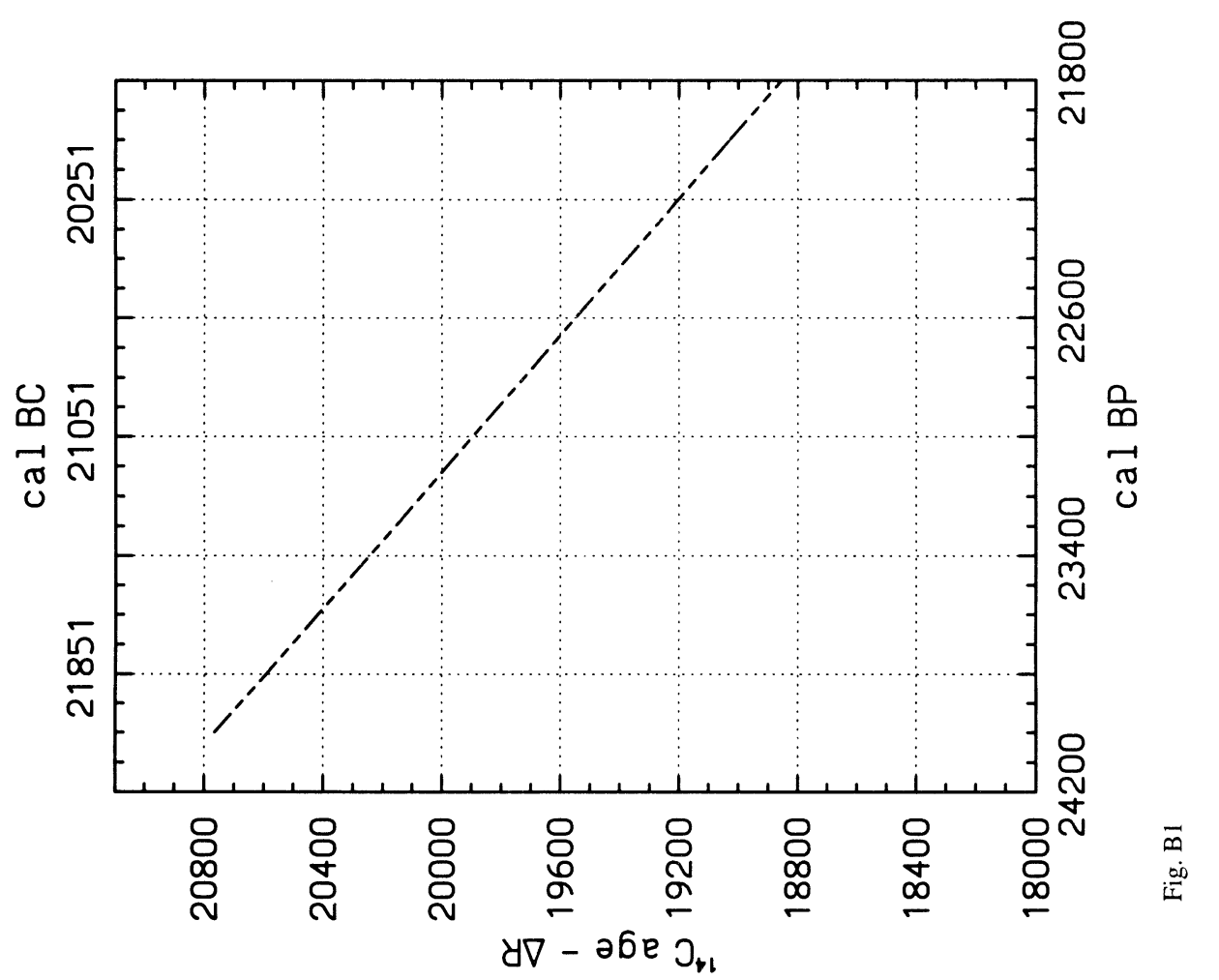



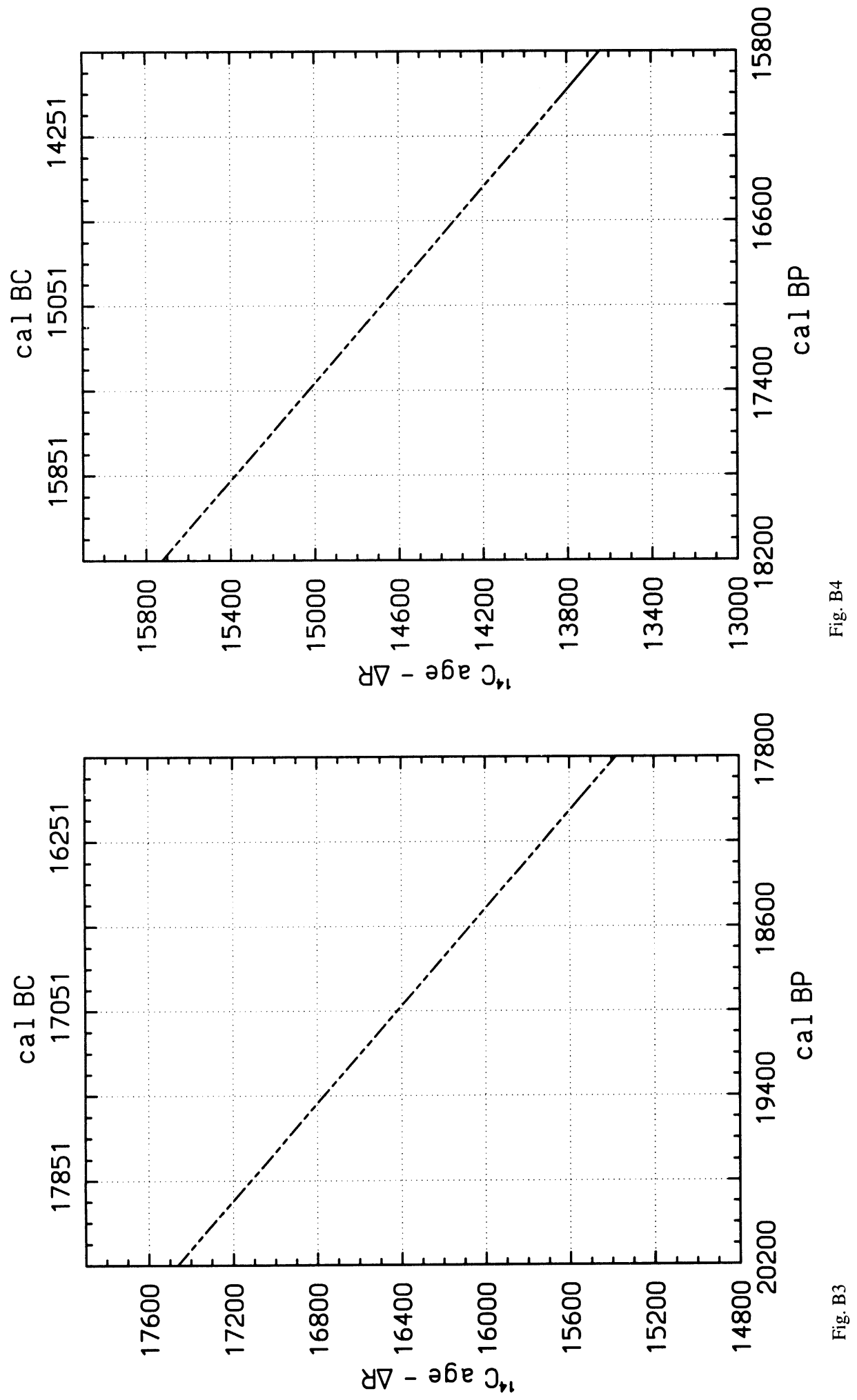

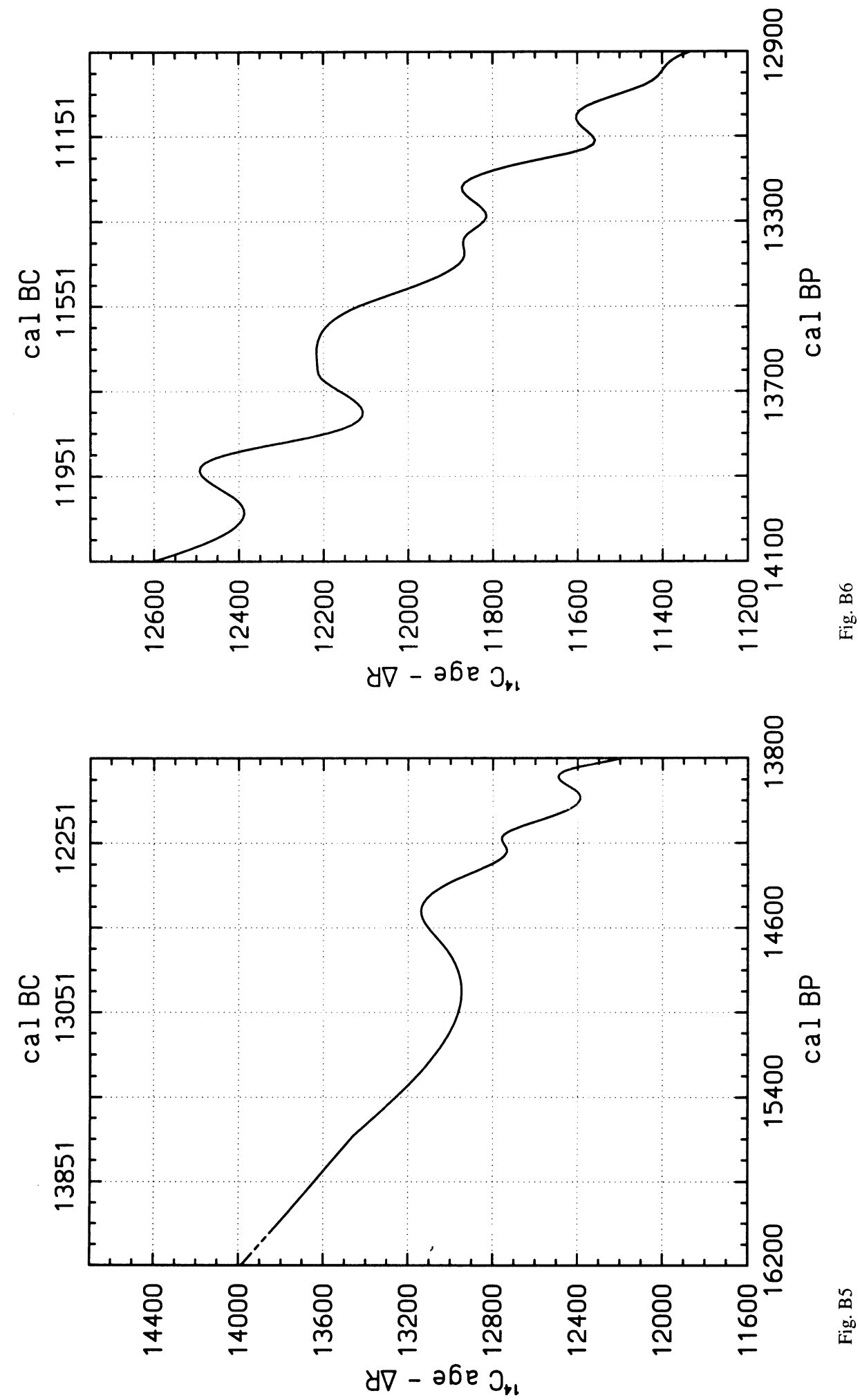

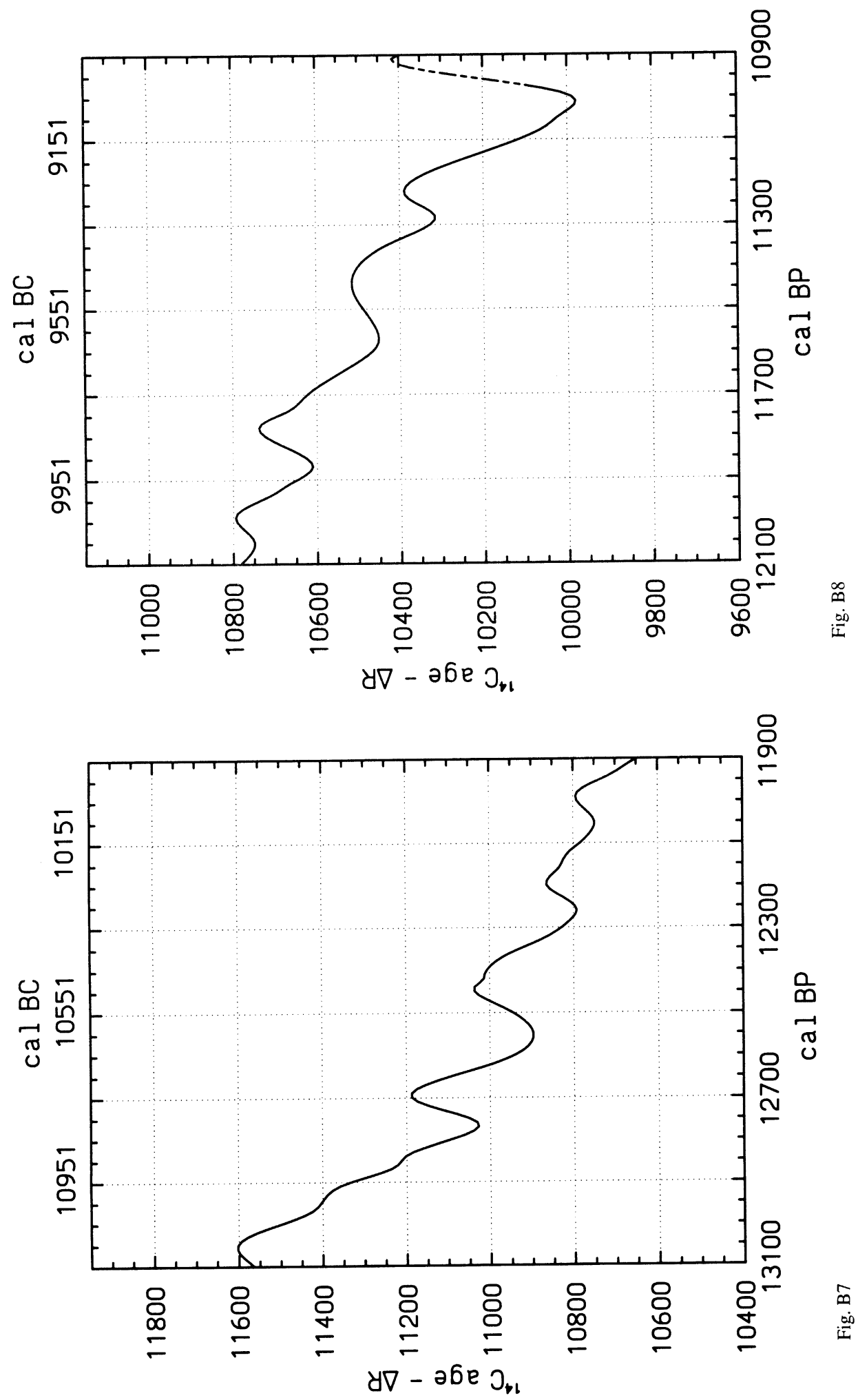

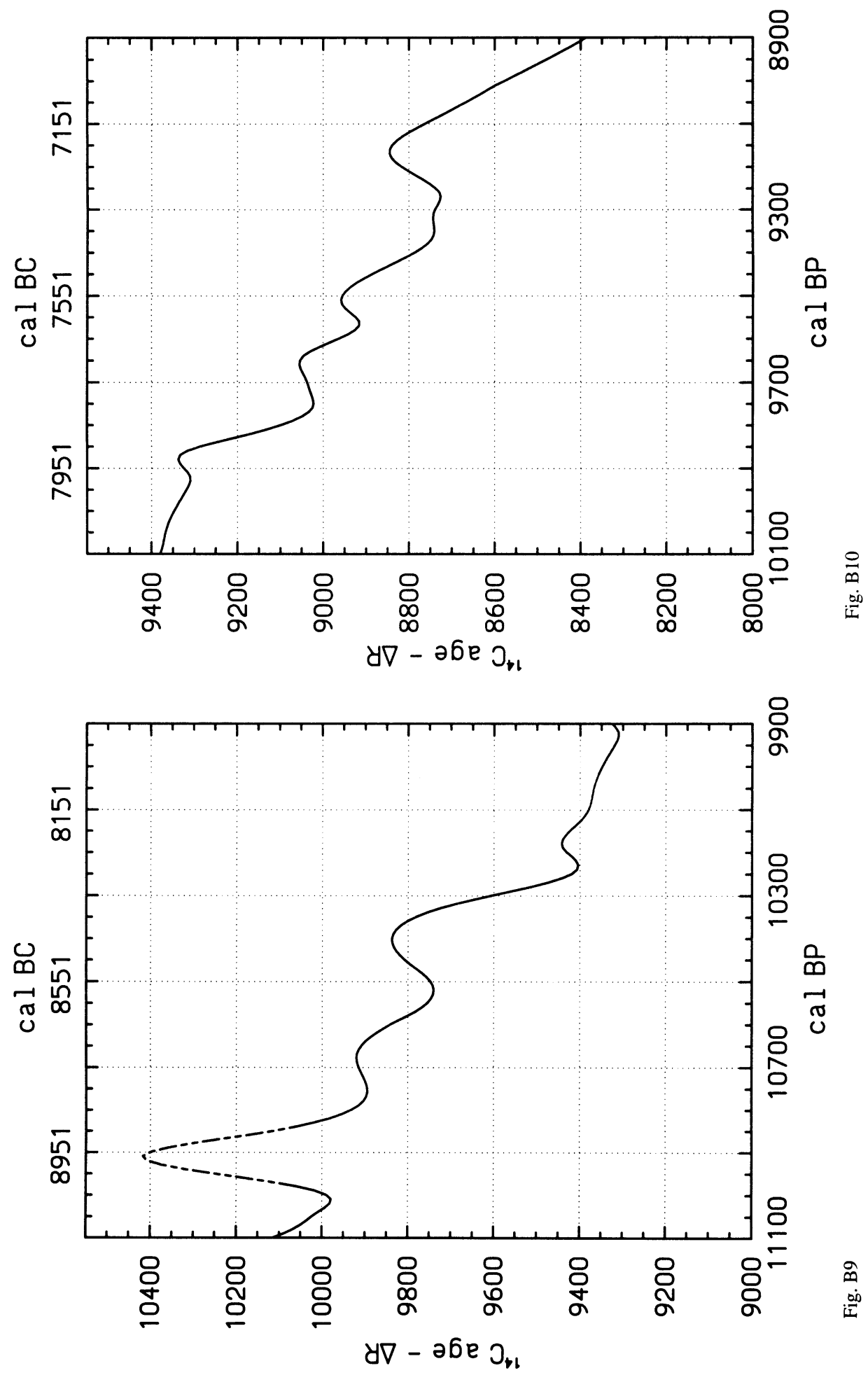

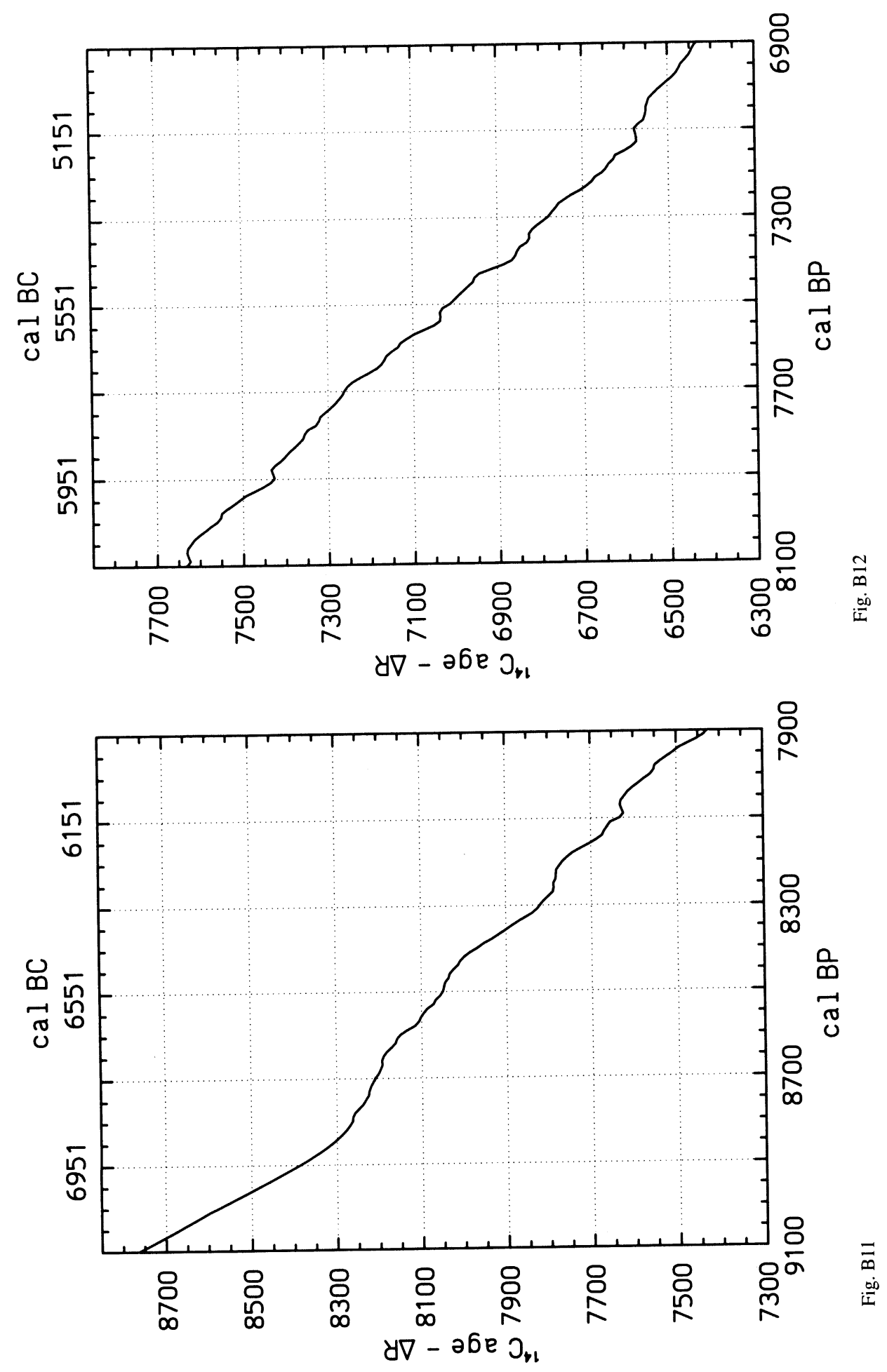

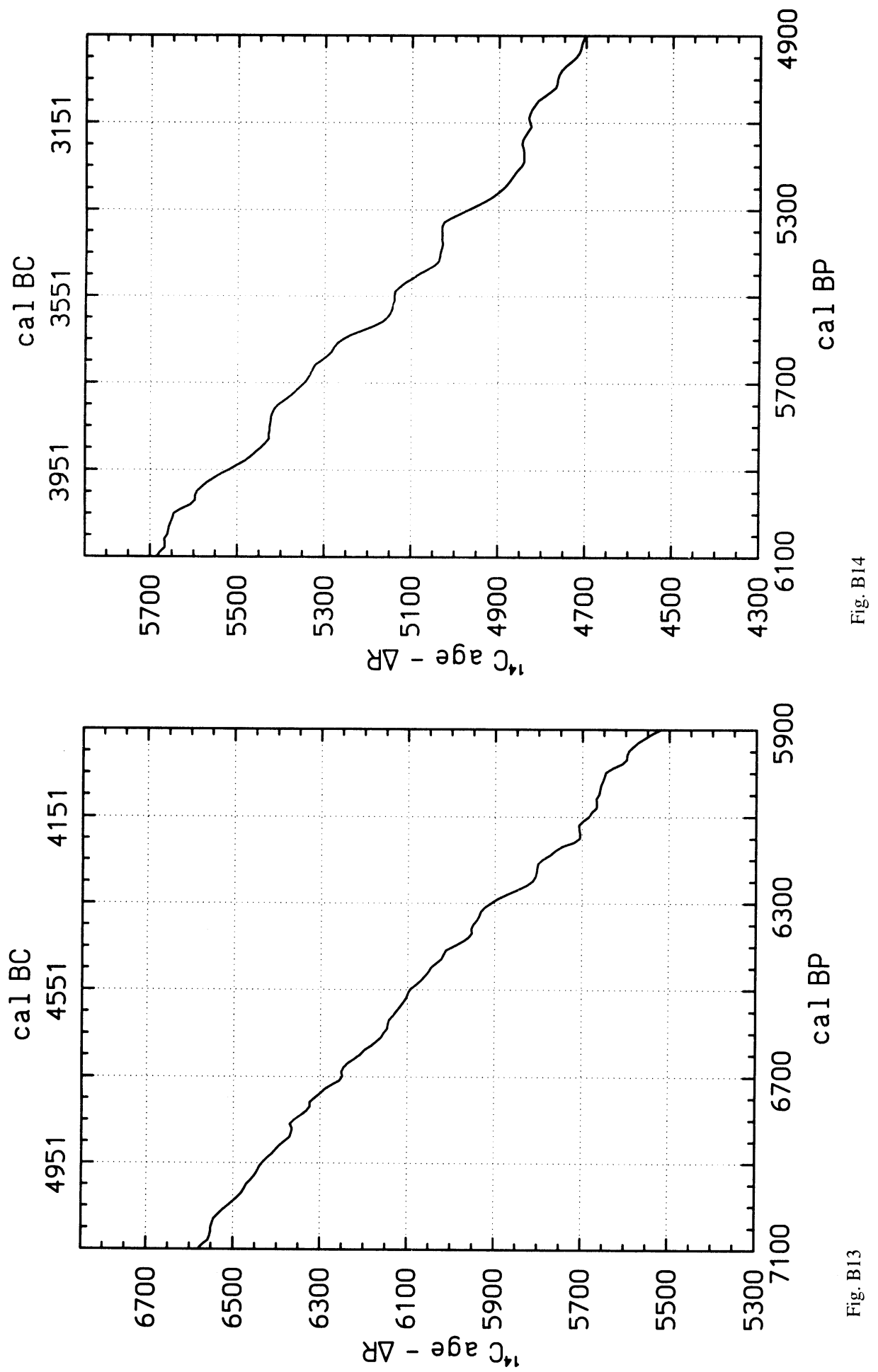

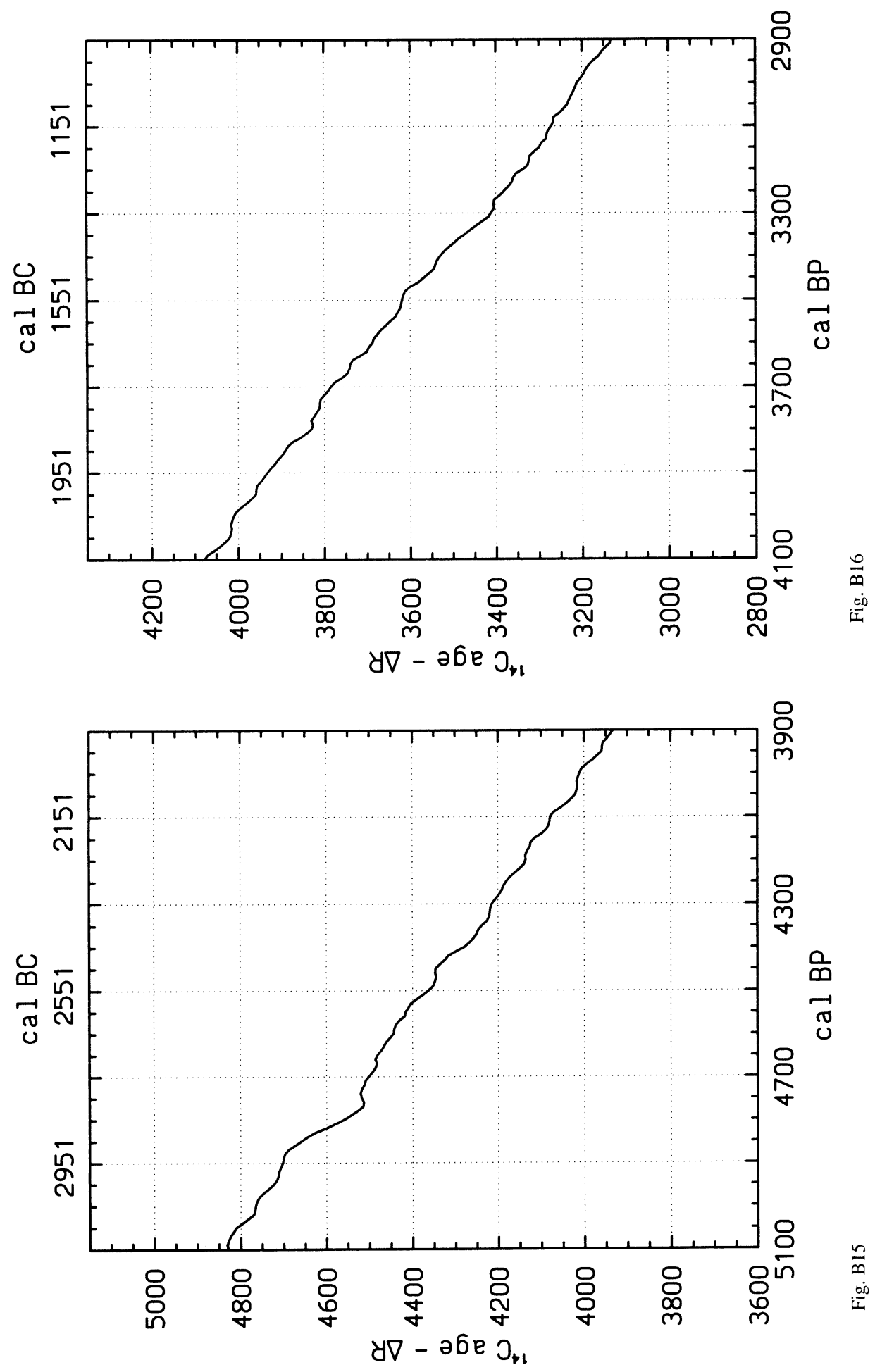

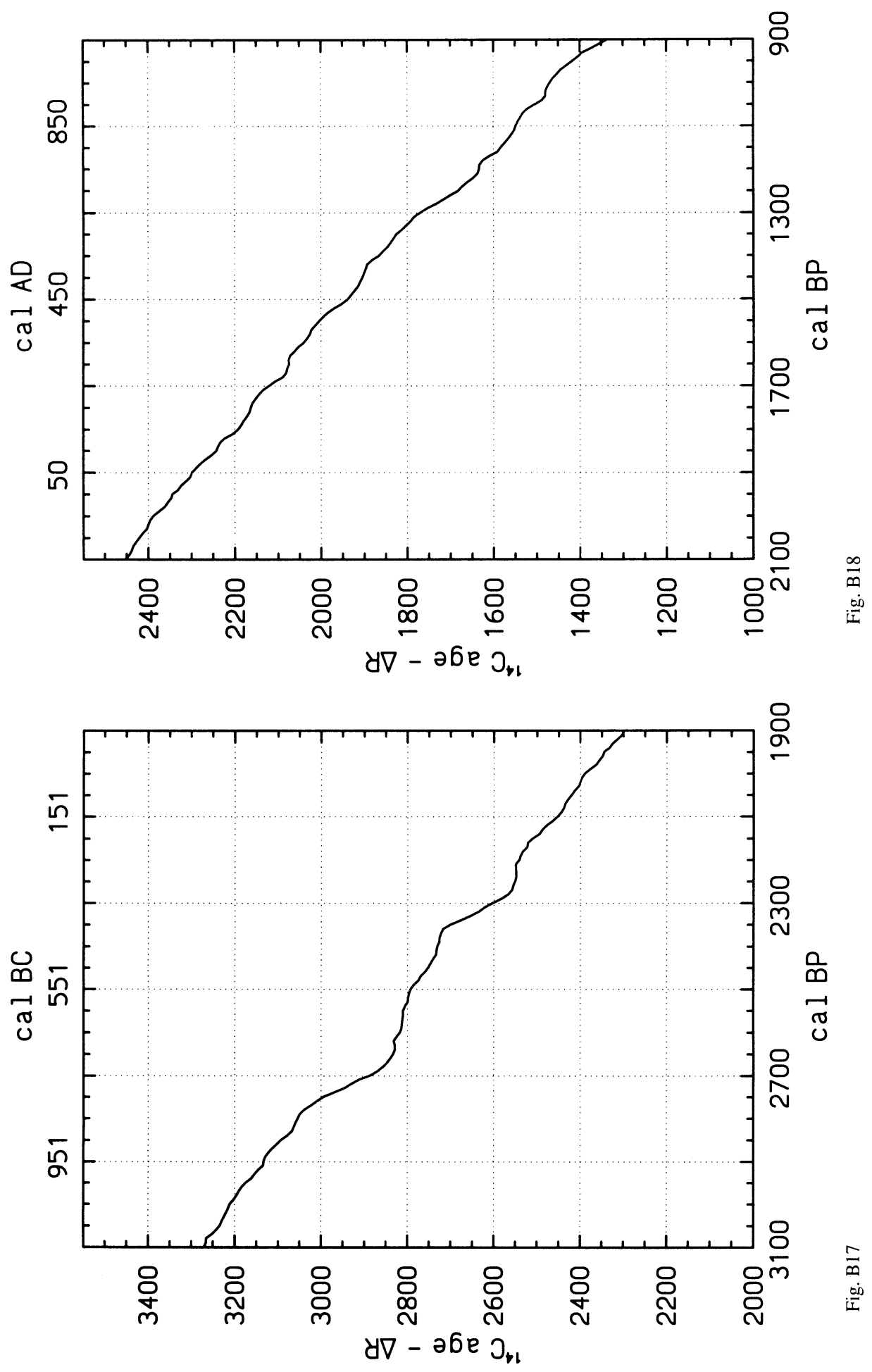


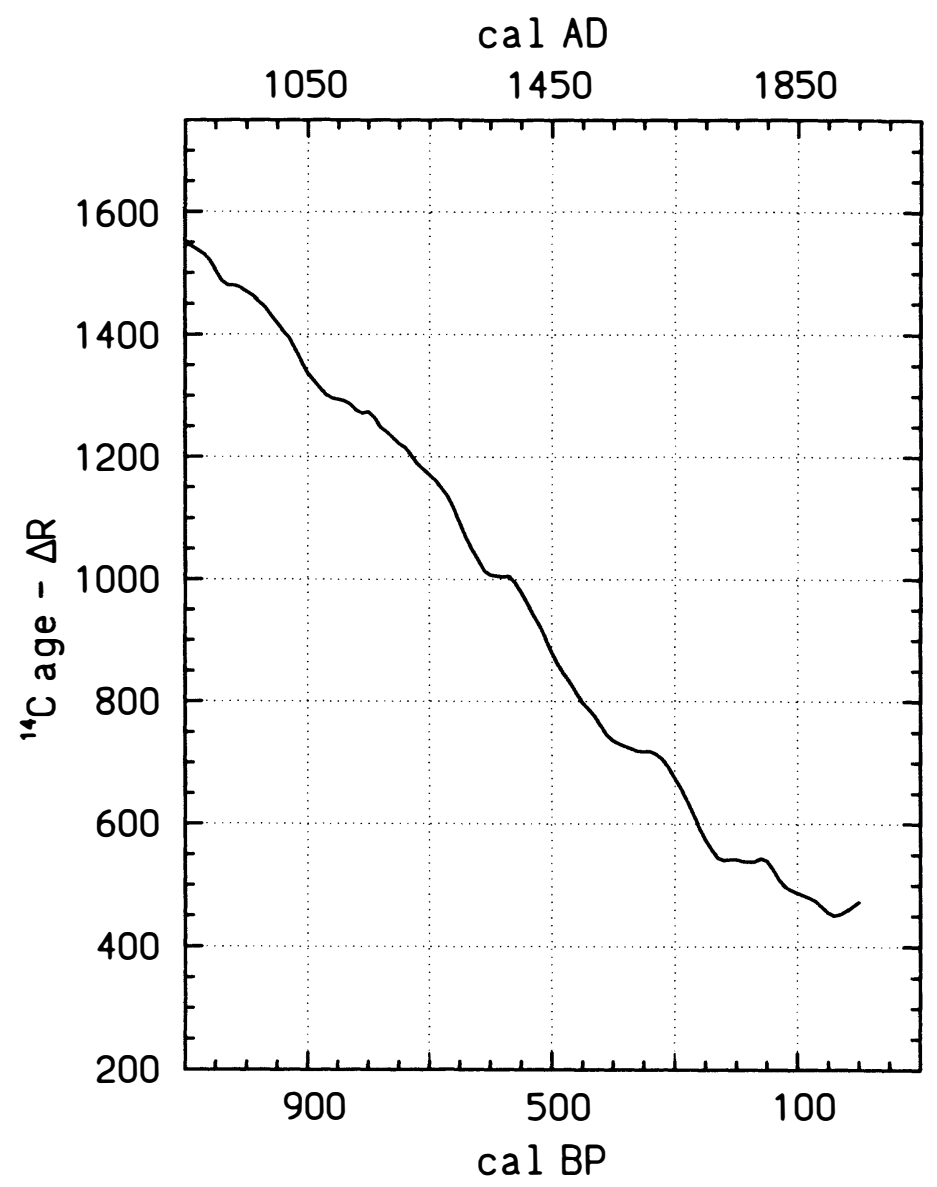

Fig. B19 